\title{
Loss of phosphodiesterase 4D mediates acquired triapine resistance via Epac-Rap1-Integrin signaling
}

\author{
Walter Miklos ${ }^{1}$, Petra Heffeter ${ }^{1,3}$, Christine Pirker $^{1}$, Sonja Hager ${ }^{1}$, Christian R. \\ Kowol ${ }^{2,3}$, Sushilla van Schoonhoven ${ }^{1}$, Mirjana Stojanovic ${ }^{1}$, Bernhard K. Keppler ${ }^{2,3}$, \\ Walter Berger ${ }^{1,3}$ \\ ${ }^{1}$ Department of Medicine I, Institute of Cancer Research and Comprehensive Cancer Center, Medical University of Vienna, \\ A-1090 Vienna, Austria \\ ${ }^{2}$ Institute of Inorganic Chemistry, University of Vienna, A-1090 Vienna, Austria \\ ${ }^{3}$ Research Platform "Translational Cancer Therapy Research", University Vienna and Medical University Vienna, Vienna, Austria \\ Correspondence to: Walter Berger, email: walter.berger@meduniwien.ac.at
}

Keywords: triapine-resistance, phosphodiesterase, Epac, Rapl, integrin

Received: March 14, 2016

Accepted: August 24, 2016

Published: September 02, 2016

\section{ABSTRACT}

Triapine, an anticancer thiosemicarbazone, is currently under clinical investigation. Whereas promising results were obtained in hematological diseases, trials in solid tumors widely failed. To understand mechanisms causing triapine insensitivity, we have analysed genomic alterations in a triapine-resistant SW480 subline (SW480/tria). Only one distinct genomic loss was observed specifically in SW480/tria cells affecting the phosphodiesterase 4D (PDE4D) gene locus. Accordingly, pharmacological inhibition of PDE4D resulted in significant triapine resistance in SW480 cells. Hence, we concluded that enhanced cyclic AMP levels might confer protection against triapine. Indeed, hyperactivation of both major downstream pathways, namely the protein kinase A (PKA)-cAMP response element-binding protein (Creb) and the exchange protein activated by CAMP (Epac)-Ras-related protein 1 (Rap1) signaling axes, was observed in SW480/tria cells. Unexpectedly, inhibition of PKA did not re-sensitize SW480/tria cells against triapine. In contrast, Epac activation resulted in distinct triapine resistance in SW480 cells. Conversely, knock-down of Epac expression and pharmacological inhibition of Rap1 re-sensitized SW480/tria cells against triapine. Rap1 is a well-known regulator of integrins. Accordingly, SW480/tria cells displayed enhanced plasma membrane expression of several integrin subunits, enhanced adhesion especially to RGD-containing matrix components, and bolstered activation/expression of the integrin downstream effectors Src and RhoA/Rac. Accordingly, integrin and Src inhibition resulted in potent triapine resensitization especially of SW480/tria cells. In summary, we describe for the first time integrin activation based on CAMP-Epac-Rap1 signaling as acquired drug resistance mechanism. combinations of triapine with inhibitors of several steps in this resistance cascade might be feasible strategies to overcome triapine insensitivity of solid tumors.

\section{INTRODUCTION}

Conversion of ribonucleotides to deoxyribonucleotides is the rate-limiting step during DNA synthesis catalyzed by ribonucleotide reductase (RR) [1]. Because of the high proliferation rate of tumor cells, RR is overexpressed in many different cancer types and represents a potent target in anticancer treatment [2]. $\mathrm{RR}$ is composed of the catalytic R1 and the enzymatic
R2 subunit. The latter comprises a tyrosyl radical within an iron-containing center essential for the enzymatic activity [3]. Consequently, iron depletion in cancer cells leads to deoxyribonucleotide deprivation and further to cell cycle arrest and apoptosis. Therefore, iron-chelating drugs have been developed as targeted anticancer drugs. Several prominent representatives belong to the class of thiosemicarbazones (TSC) [1], with 3-aminopyridine2-carboxaldehyde thiosemicarbazone (triapine or 3-AP) 
as the best studied example. While promising results for triapine were obtained in clinical studies concerning hematological diseases $[2,4]$, the one in solid tumors widely failed [5-8]. However, the mechanisms underlying triapine insensitivity of solid tumors are widely unknown.

Intrinsic and acquired anticancer drug resistance might be based on overexpression of ATP-binding cassette (ABC) drug efflux pumps causing a phenomenon termed multi-drug resistance (MDR). With regard to $\mathrm{ABC}$-transporters, others and we have shown that triapine-selection might cause ABCB1 (also known as P-glycoprotein) overexpression [9, 10]. However, triapine accumulation was not reduced significantly in $\mathrm{ABCB} 1$-overexpressing cells and $\mathrm{ABCB} 1$ inhibition failed to significantly re-sensitize towards triapine. This argues against $\mathrm{ABCB} 1$ as a major triapine-resistance factor [10]. Alternatively, drug resistance might be based on hyperactivation of different survival and antiapoptosis pathways. One of the involved molecules, attracting increasing attention during the last years, represents cyclic adenosine monophosphate (cyclic AMP, cAMP) [11]. cAMP is one of the most abundant second messengers regulating various physiological processes like cell survival, differentiation, proliferation and apoptosis [12]. cAMP is catalyzed from ATP via adenylate cyclase activated by $\mathrm{G}$ protein-coupled receptors [13]. The negative regulators of cAMP belong to the family of phosphodiesterases (PDE), especially PDE4, which hydrolyze cAMP to AMP [14, 15]. Enhanced cAMP signaling has recently been identified as a major player in resistance to cytotoxic drugs, but also for example in vemurafenib therapy failure of BRAF-mutant melanoma [11].

One major downstream target of cAMP is cAMPdependent protein kinase A (protein kinase A, PKA) [16], a serine/threonine kinase consisting of two catalytic and two regulatory subunits [17]. Binding of the second messenger to the regulatory subunits leads to dissociation of the complex and the free catalytic subunits phosphorylate a variety of proteins [18]. One PKA substrate is the transcription factor cAMP-responsive element-binding protein (Creb). Subsequent, Creb binds as homo- or heterodimers to cAMP-responsive elements within target gene promoters [19], thus activating transcription of several growth and survival genes including microphthalmia-associated transcription factor (MITF) [20], bcl-2 [21], and cyclin D1 [22].

Besides PKA, another downstream target of cAMP, namely exchange protein activated by cAMP (Epac), was more recently discovered [23]. Epac acts as cAMPactivated Rap guanine-nucleotide-exchange factor for the GTPase Ras-related protein 1 (Rap1), which it activates independently of PKA [24]. Rap1 signaling leads to various cellular responses including integrin-mediated cell adhesion [25], as well as activation of the mitogenactivated protein kinase signaling pathway [26], Src [27], and downstream GTPases of the Rho/Rac family via a crosstalk between Src and focal adhesion kinase (FAK) [28]. Accordingly, Almahariq et al. have shown that Epac plays an important role in pancreatic cancer cell migration and invasion via altered integrin expression [29].

In the present study, we have uncovered a key role of the cAMP signaling pathway in acquired triapine resistance. An Epac-Rap1-integrin survival program was identified as the responsible downstream mediator. These findings offer the chance for synergistic combination treatment schemes involving triapine.

\section{RESULTS}

\section{Genomic characterization of triapine-resistant SW480 cells}

A triapine-resistant SW480 subline (SW480/ tria) was generated as described by Miklos et al [10]. Cytotoxicity assays were performed to prove insensitivity against triapine (Figure 1A) and a $>56$-fold resistance (at $\mathrm{IC}_{50}$ ) in comparison to the parental cell line was detected. To identify molecular factors contributing to triapine resistance, genome wide gene dose changes (gains or losses) were analyzed by direct and indirect aCGH. While multiple chromosomal changes were obvious in the parental cell line (Supplementary Figure S1A), indirect aCGH of SW480/tria versus SW480 cells indicated that triapine selection induced only minor further DNA dose changes (Supplementary Figure S1B). Distinct genomic gains in SW480/tria as compared to the parental cells were completely missing. In contrast, the resistant subline harbored a specific loss at chromosome 5q12 (Figure $1 B)$. The deleted region affected only one gene, namely phosphodiesterase 4D (PDE4D). As expected, gene loss resulted in massive downregulation of the respective $P D E 4 D$ mRNA (Figure 1C) and protein expression (Figure 1D).

\section{PDE4D inhibition protects against triapine in parental $S W 480$ cells}

Consequently, we hypothesized that PDE4D augments triapine-mediated anticancer activity probably via down-regulation of cAMP. To support this assumption, we investigated whether the small molecule PDE4 inhibitor rolipram protects SW480 cells against triapine. Indeed, cell viability assays (72 $\mathrm{h}$ exposure) proved that PDE4 inhibition by rolipram resulted in decreased sensitivity of SW480 cells (Figure 2A) as well as HCT116 cells (Supplementary Figure S2A) to triapine. In contrast, no significant effects were seen in the already triapine-resistant SW480/tria cells (Figure 2B). Long-term colony formation assay (10 days exposure) confirmed this protective effect in parental SW480 cells already at a lower triapine concentration $(0.5 \mu \mathrm{M}$; Figures $2 \mathrm{C}$, 
A
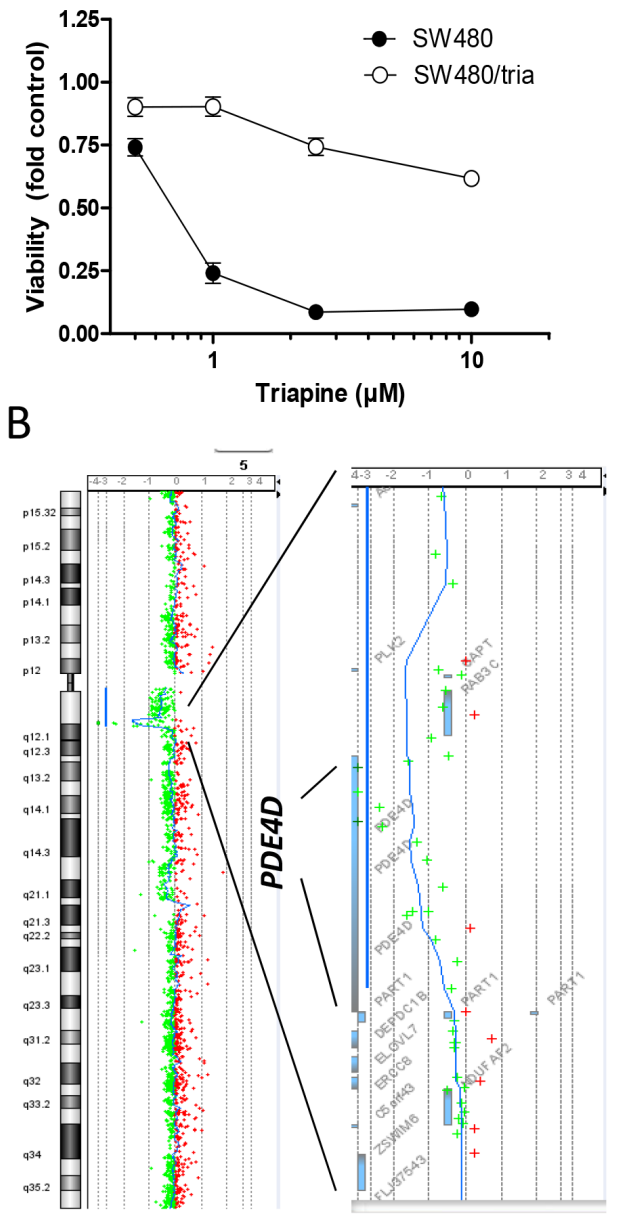

\begin{tabular}{|l|l|l|}
\hline Name of Gene & SW480 & $\square$ SW480Tria \\
\hline PDE4D & -0.520 & -0.478 \\
\hline PDE4D & -0.286 & -1.586 \\
\hline PDE4D & -0.178 & -5.480 \\
\hline PDE4D & -0.429 & -4.355 \\
\hline PDE4D & -0.419 & -2.568 \\
\hline PDE4D & -0.188 & -6.019 \\
\hline PDE4D & -0.513 & -2.415 \\
\hline PDE4D & -0.163 & -1.344 \\
\hline PDE4D & -0.367 & -1.053 \\
\hline PDE4D & -0.531 & -0.632 \\
\hline PDE4D & 0.019 & -1.009 \\
\hline PDE4D & -0.184 & -1.444 \\
\hline PDE4D & -0.215 & -1.616 \\
\hline PDE4D & -0.724 & 0.104 \\
\hline PDE4D & -0.353 & -0.812 \\
\hline PDE4D & -0.139 & -0.241 \\
\hline PDE4D & -0.227 & -0.389 \\
\hline \hline
\end{tabular}

C
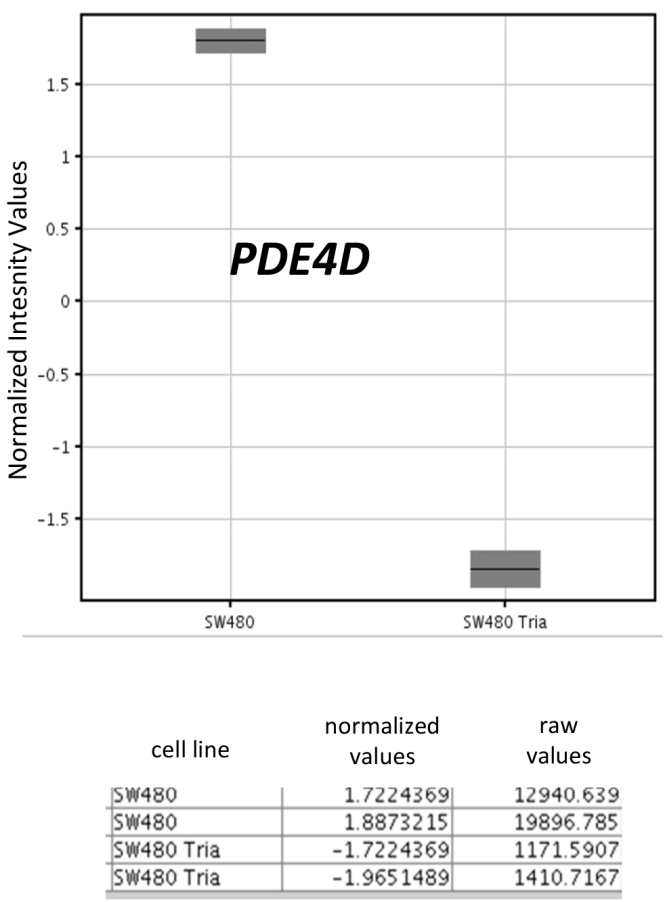

D
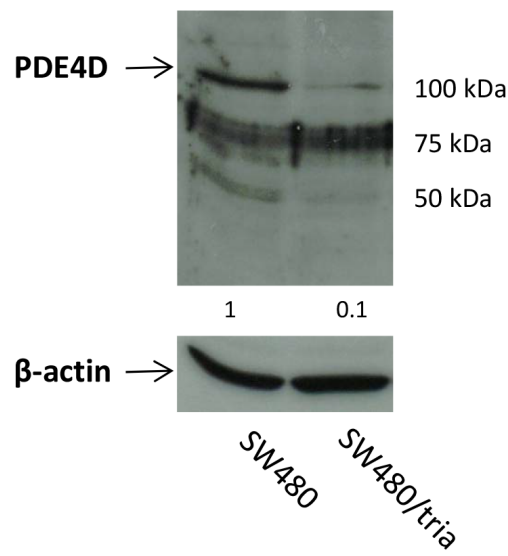

Figure 1: Characterization of a colon cancer cell line with acquired triapine resistance. A. SW480 and SW480/tria cells were treated with the indicated concentrations of triapine. After $72 \mathrm{~h}$ treatment, cell viability was determined by MTT assay. The values given are means and standard deviations (SD) of one representative experiment out of three performed in triplicate. B. Gene dose changes of SW480/tria in comparison to SW480 cells were investigated by indirect aCGH (compare Supplementary Figure S1) using Cy5- and Cy3-labeled DNA, respectively. Results for whole chromosome 5 (left) are opposed to an enlarged region at 5q12 (right) containing the $P D E 4 D$ gene. Each (+) indicates the position of one oligonucleotide within this region. Log2 ratios of Cy5-labeled SW480/tria and Cy3labeled SW480 DNA of all PDE4D oligonucleotides on the microarray are listed at the bottom. C. mRNA expression levels for PDE4D in SW480 and SW480/tria cells were assessed by whole genome gene expression microarrays. Three independent $P D E 4 D$ oligonucleotides were spotted on the array and gave comparable results. Data for oligonucleotide A_33_P3389653, recognizing all PDE4D mRNA splice variants, are shown. Normalized values for two replicates of SW480 and SW480/tria cells indicate massive downregulation of PDE4D mRNA in the SW480/tria as compared to the parental cell line. Raw values depict the absolute dye intensity (Cy3 or Cy5) measured for the PDE4D oligonucleotide on the microarray. D. PDE4D expression using total protein extracts of SW480 vs. SW480/tria cells was evaluated by Western blotting. $\beta$-actin was used as loading control. 
A

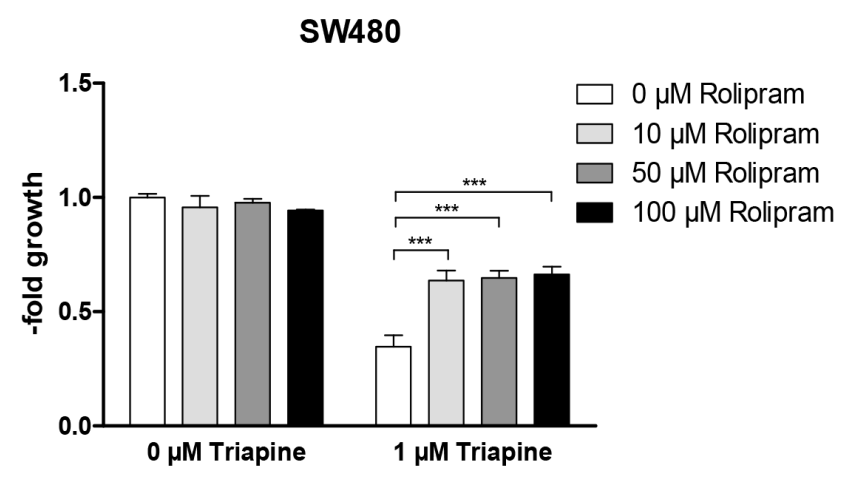

C

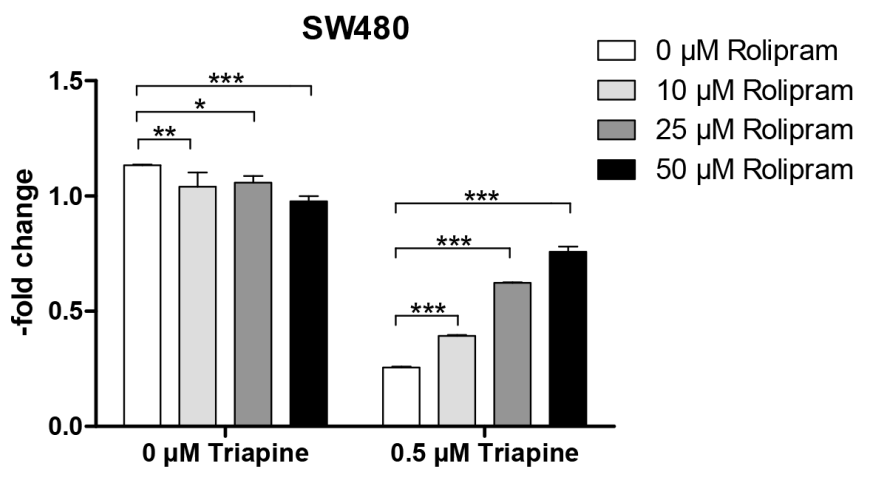

$E$

SW480

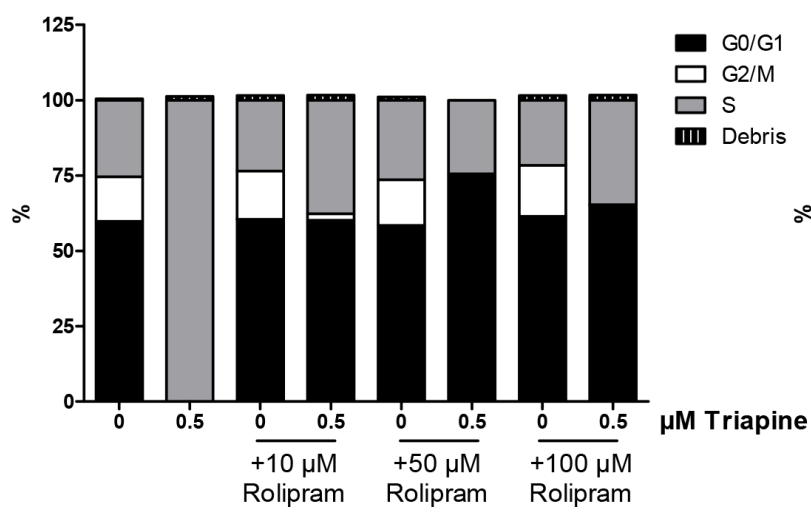

B

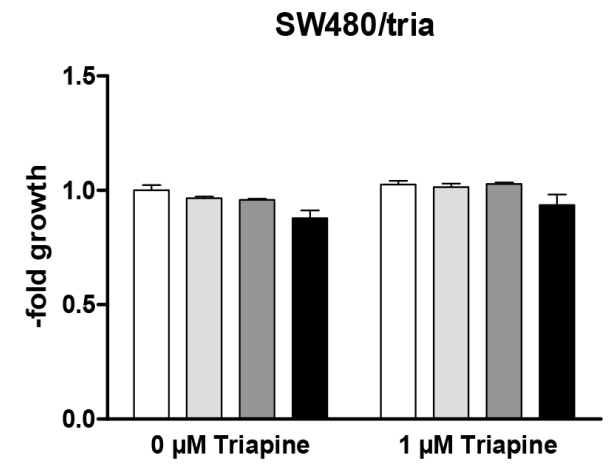

D

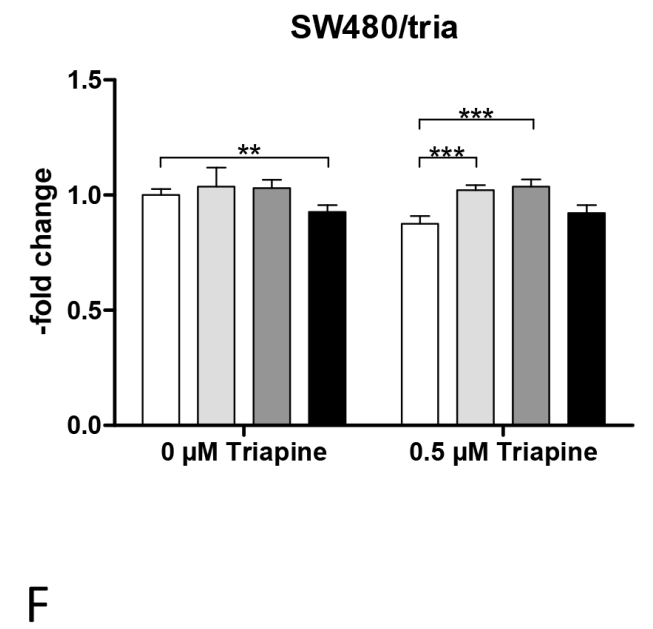

SW480/tria

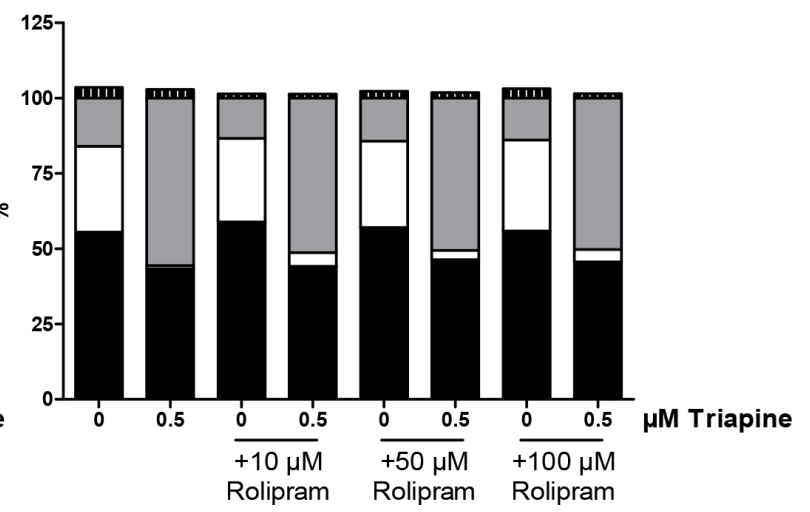

Figure 2: Impact of PDE4D inhibition on triapine response in SW480 and SW480/tria cells. A and B. Cell viability of SW480 (A) and SW480/tria (B) cells treated for $72 \mathrm{~h}$ with the PDE4D inhibitor rolipram at the indicated concentrations alone and in combination with $1 \mu \mathrm{M}$ triapine was determined by MTT assay. The values given are means and SD of one representative experiment out of three performed in triplicate. Statistical analysis was performed by two-way ANOVA $(* * * P<0.001)$. C and D. Colony formation potency of SW480 (C) and SW480/tria cells (D) treated with the indicated concentrations of rolipram alone and in combination with $0.5 \mu \mathrm{M}$ triapine was evaluated. After 10 days of drug exposure cells were stained with crystal violet and quantified microscopically. The values given are means and SD of two experiments in duplicate. Statistical analysis was performed by Student's t-test $\left(* P<0.05, * * P<0.01,{ }^{* * *} P<0.001\right)$. E and F. Cell cycle distribution of SW480 (E) and SW480/tria cells (F) was determined after $24 \mathrm{~h}$ exposure to the indicated concentrations of triapine alone and in combination with rolipram. Propidium iodide staining and flow cytometric measurements were performed and percentages of cells in $\mathrm{G} 0 / \mathrm{G} 1, \mathrm{~S}$, and $\mathrm{G} 2 / \mathrm{M}$ phases are indicated. 
2D and Supplementary Figures S2B, S2C). As triapine is a known ribonucleotide reductase inhibitor [30], we further analysed the cell cycle distribution in the drug combination setting. Interestingly, the almost complete S-phase arrest induced by $0.5 \mu \mathrm{M}$ triapine in SW480 cells was distinctly abolished by rolipram (Figure 2E). While reduction of the G2/M subpopulation by triapine was also detected in SW480/tria cells, the massive S-phase arrest was missing. Furthermore, co-treatment with rolipram only marginally reversed the G2/M-phase loss induced by triapine (Figure 2F).

\section{The cAMP-PKA-Creb signal axis is not a major regulator of $\mathrm{PDE} 4 \mathrm{D}$-promoted triapine response}

One of the major cellular signaling pathways activated by cAMP is the PKA-Creb module [16]. Therefore, we investigated whether alterations in the cAMP-PKA-Creb pathway were responsible for triapine resistance mediated by PDE4D loss. Indeed, stimulation of cAMP with forskolin significantly attenuated triapine response in SW480 cells but not in the triapine-selected subline (Figure 3A). Forskolin as single drug did not markedly alter viability of SW480 cells but slightly reduced the one of SW480/tria cells (Supplementary Figure S3A). Furthermore, hyperactivation of PKA in SW480/tria cells compared to the parental cell line was demonstrated by a strong hyperphosphorylation of PKA substrates (Figure 3B). More specifically, expression of the major PKA downstream transcription factor Creb was slightly enhanced and its activating phosphorylation at serine 133 massively increased in the triapine-resistant subline (Figure 3C). Thus, we hypothesized that inhibition of the PKA/Creb signal by PKA inhibitor H-89 should resensitize SW480/tria cells against triapine. The inhibitor alone had no major influence on cell viability in both cell lines (Supplementary Figure S3B). Surprisingly, however, co-application with $\mathrm{H}-89$ did not significantly sensitize SW480/tria cells against triapine and even tended to protect the parental cell line (Figure 3D) despite clear-cut reduction of Creb phosphorylation in both cell models (Supplementary Figure S3C). This demonstrates that the PKA-Creb signal axis is not the major player involved in cAMP-mediated triapine resistance.

\section{The cAMP-Epac-Rap1 signal axis distinctly contributes to acquired triapine resistance}

An alternative target of cAMP is Epac [23], a guanine nucleotide exchange factor selectively activating the Rap1 protein [24]. Therefore, we investigated whether Epac and Rap1 are involved in acquired triapine resistance. Indeed, both Epac and Rap1 were markedly overexpressed in the triapine-resistant SW480 subline (Figure 4A). Activation of Epac by the cell-permeable activator 007-AM led to a massively reduced triapine response selectively in SW480 but not in SW480/tria cells (Figure 4B). Accordingly, Epac knock-down by siRNA (Supplementary Figure S4A) led to significant resensitization of the resistant subline to triapine, whereas no effect was seen in the parental SW480 cells (Figure 4C). In addition to overexpression, Rap1 was clearly hyperactivated in the triapine-resistant subline (Supplementary Figure S4B). Furthermore, triapine treatment led to a further increase of Rap1 expression levels in SW480/tria but not in parental SW480 cells (Figure 4D). Rap1 needs to be prenylated for correct localization and activation [31]. Accordingly, deprenylation of Rap1 as a consequence of mevalonate pathway inhibition by zoledronic acid led to higher amounts of deprenylated Rap1 in SW480/tria cells especially when co-administered with triapine (Figure 4D). SW480/tria cells were slightly but significantly hypersensitive against zoledronic acid as a single drug in comparison to the parental cell line (Supplementary Figure S4C). Furthermore, Rap1 inhibition by zoledronic acid resulted in re-sensitization of SW480/tria cells to triapine but had almost no impact in parental cells (Figure 4E). This synergistic effect was confirmed by combination index values $<0.8$ especially in the resistant cell model (Supplementary Figure S4D). These data strongly indicate that triapine resistance is mediated at least in part via the cAMP-Epac-Rap1 signal axis.

\section{Epac-Rap1-mediated triapine resistance involves integrin alterations}

Next, we aimed to clarify how the Epac-Rap1 signaling cascade mediates triapine resistance. Therefore, we investigated the role of integrins, major downstream targets of Rap1 [32], in acquired triapine resistance. Expression of several integrin $\alpha$ and $\beta$ subunits was analyzed by Western blot in plasma membraneenriched fractions of SW480 as compared to SW480/ tria cells. The amounts of membrane-associated integrin subunits $\alpha v, \alpha 5, \beta 1$ and $\beta 5$ were distinctly enhanced in SW480/tria as compared to SW480 cells (Figure 5A). Integrin $\beta 1$ overexpression was also confirmed by immunhistochemical staining in the SW480/tria as compared to the SW480 xenograft in vivo (Supplementary Figure S5A, S5B). Consequently, we analyzed the impact of triapine treatment alone and in combination with cilengitide, a cyclic RGD-mimetic peptide and integrin $\alpha v$ inhibitor [33], on integrin expression in our resistance model using total protein lysates. Generally, upregulation of integrin expression in the resistant subline was somewhat lower but still distinct in the total protein lysates as compared to the cell membrane fractions, indicating more efficient cell membrane targeting of integrins in the triapine-resistant subline (Figure 5B versus $5 \mathrm{~A}$, respectively). Interestingly, triapine exposure for $24 \mathrm{~h}$ resulted in a selective and distinct up-regulation of integrin $\alpha 5$ expression in both cell lines (Figure 5B). In contrast, 
A

SW480

SW480/tria
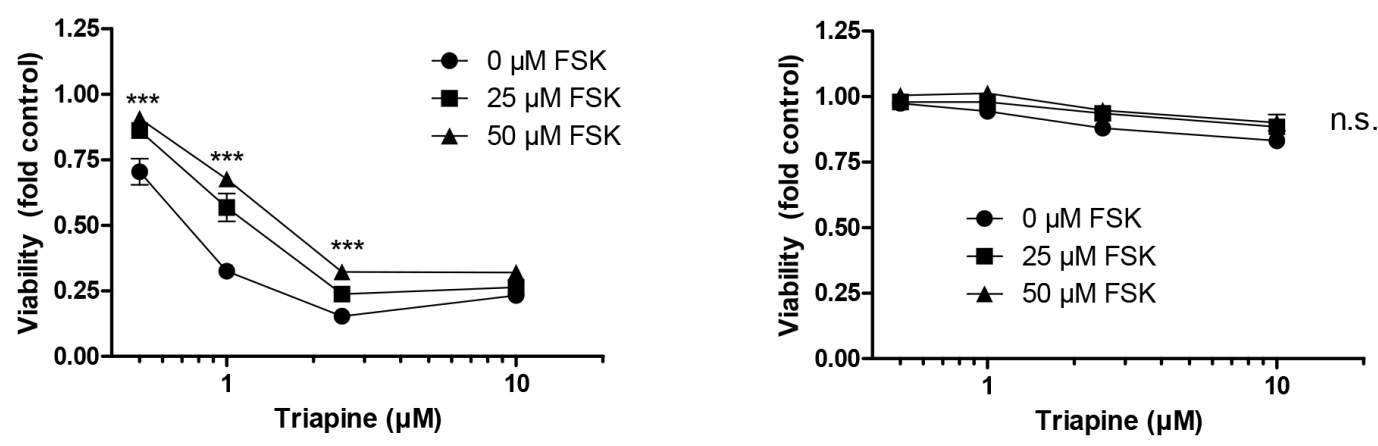

B

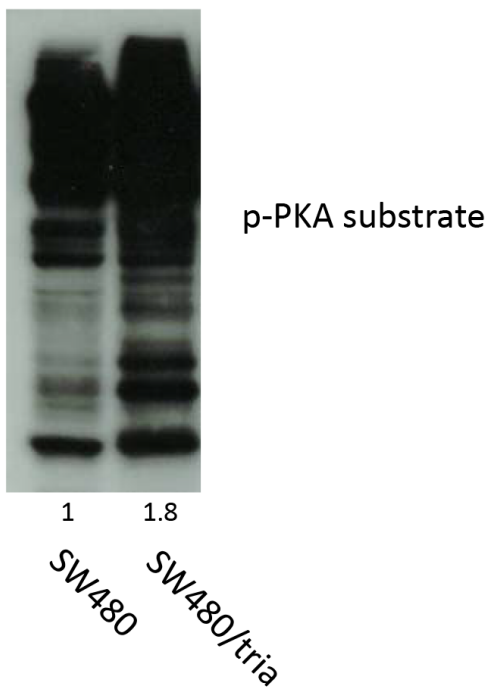

C
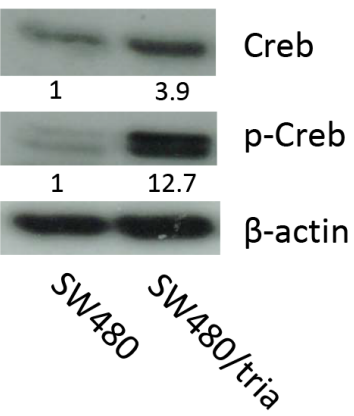

D

SW480

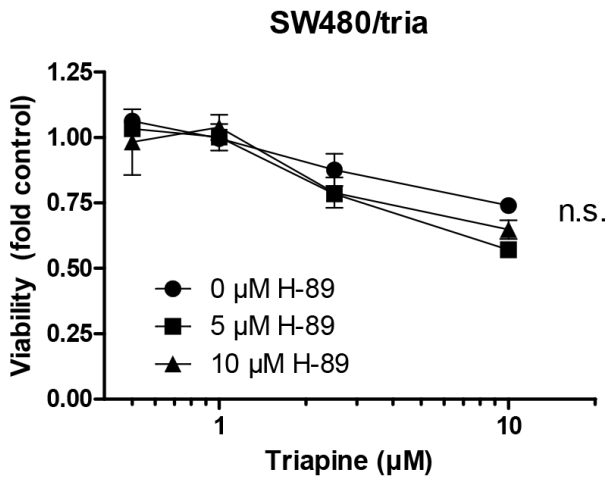

Figure 3: The PKA-Creb signaling axis is not involved in triapine resistance. A. SW480 and SW480/tria cells were treated with triapine alone and in combination with forskolin (FSK, adenylate cyclase activator) at the indicated concentrations. After $72 \mathrm{~h}$ treatment, cell viability was determined by MTT assay. The values given are means and SD of one representative experiment out of three performed in triplicate. Statistical analysis was performed by two-way ANOVA $(* * * P<0.001)$. B and D. Phosphorylation levels of multiple PKA substrates (B) and Creb (C) in total protein extracts of SW480 vs. SW480/tria cells was evaluated by Western blotting. $\beta$-actin was used as loading control. D. SW480 and SW480/tria cells were treated with triapine alone and in combination with H-89 (PKA inhibitor). After 72 $\mathrm{h}$ treatment, cell viability was determined by MTT assay. The values given are means and SD of one representative experiment out of three performed in triplicate. 


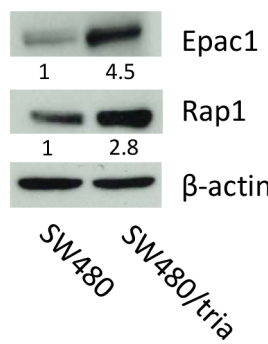

B

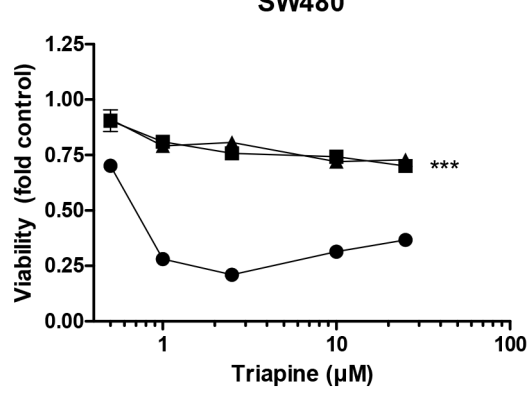

C

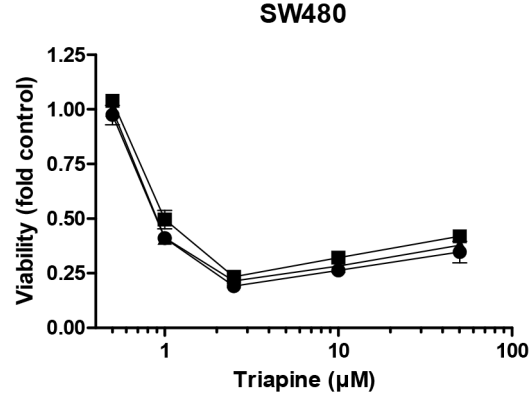

$\mathrm{E}$

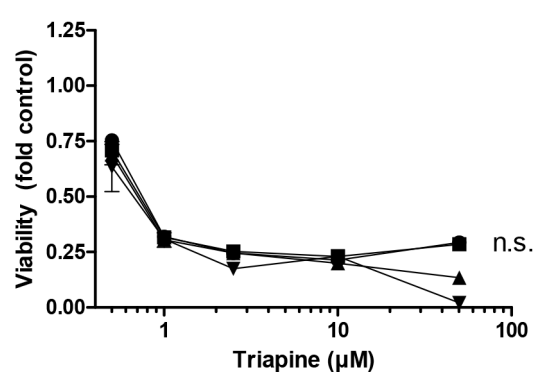

SW480/tria

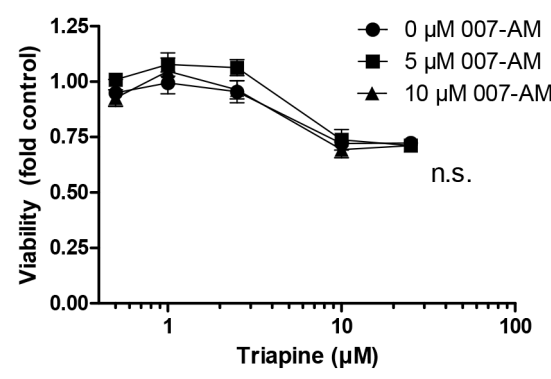

SW480/tria

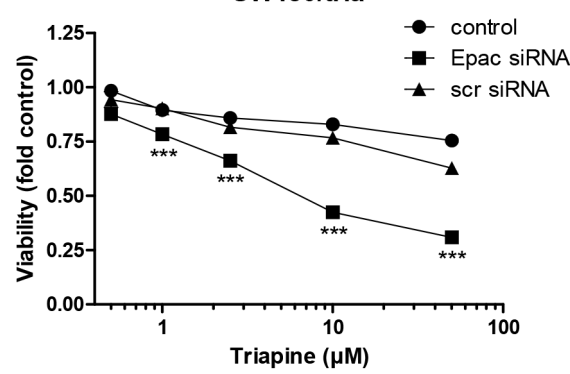

SW480/tria

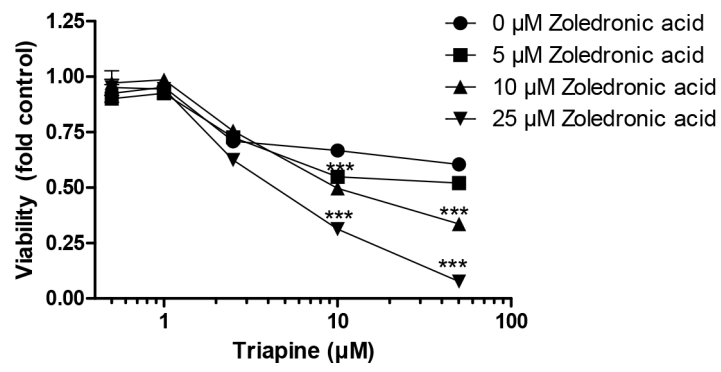

Figure 4: The Epac-Rap1 signaling axis is involved in triapine resistance. A. Expression of total Epac1 and Rap1 in protein extracts of SW480 vs. SW480/tria cells. B. SW480 and SW480/tria cells were treated with the indicated concentrations of triapine alone and in combination with 007-AM (Epac activator). After $72 \mathrm{~h}$ treatment cell viability was determined by MTT assay. The values given are means and SD of one representative experiment out of three performed in triplicate. Statistical analysis was performed by two-way ANOVA $(* * * P<0.001)$. C. SW480 and SW480/tria cells were left untreated (control) or exposed to either Epac or scrambled (scr) siRNA (both 25 $\mu \mathrm{M})$ for $48 \mathrm{~h}$ and treated with the indicated concentrations of triapine. After $72 \mathrm{~h}$ treatment, cell viability was determined by MTT assay. The values given are means and SD of one representative experiment out of three performed in triplicate. Statistical analysis was performed by two-way ANOVA $(* * * P<0.001)$. D. Levels of total and deprenylated Rap1 in SW480 as compared to SW480/tria cells treated with the indicated drugs for $24 \mathrm{~h}$ were determined by Western blotting. $\beta$-actin was used as loading control. E. SW480 and SW480/tria cells were treated with the indicated concentrations of triapine alone and in combination with zoledronic acid (inhibiting Rap1 prenylation). After 72 $\mathrm{h}$ treatment, cell viability was determined by MTT assay. The values given are means \pm SD of one representative experiment out of three performed in triplicate. Statistical analysis was performed by two-way ANOVA $(* * * P<0.001)$. 
A

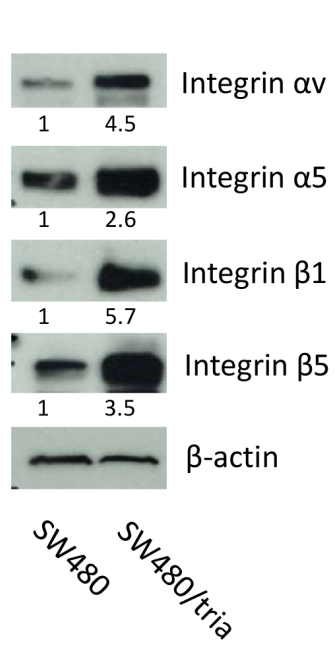

B

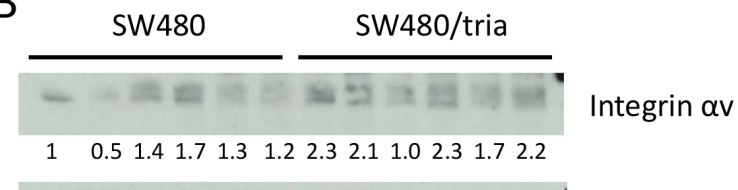

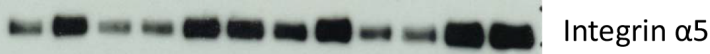

$\begin{array}{lllllllllllll}1 & 1.5 & 0.7 & 0.8 & 1.5 & 1.5 & 1.4 & 1.9 & 0.7 & 0.9 & 2.2 & 1.9\end{array}$

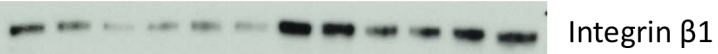

$\begin{array}{llllllllllll}1 & 0.7 & 0.4 & 0.5 & 0.6 & 0.5 & 1.8 & 1.2 & 0.9 & 0.9 & 1.1 & 1.0\end{array}$

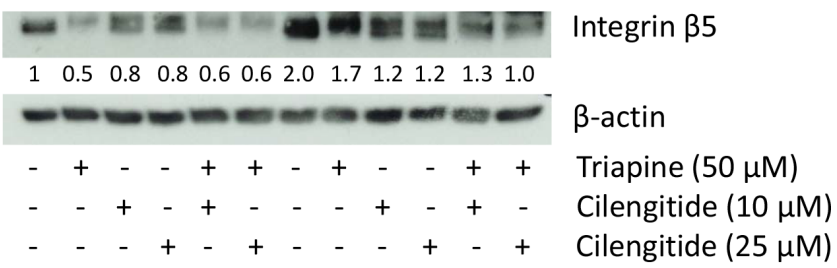

C
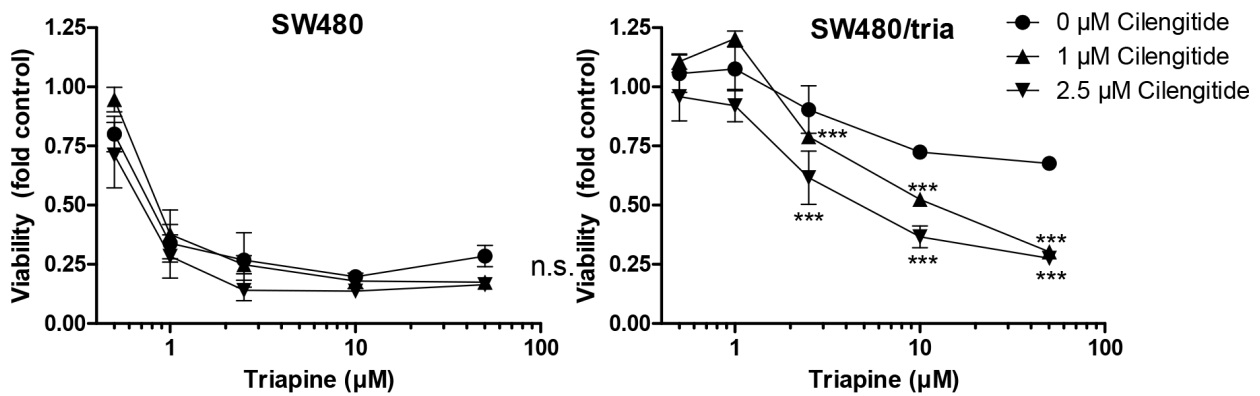

D
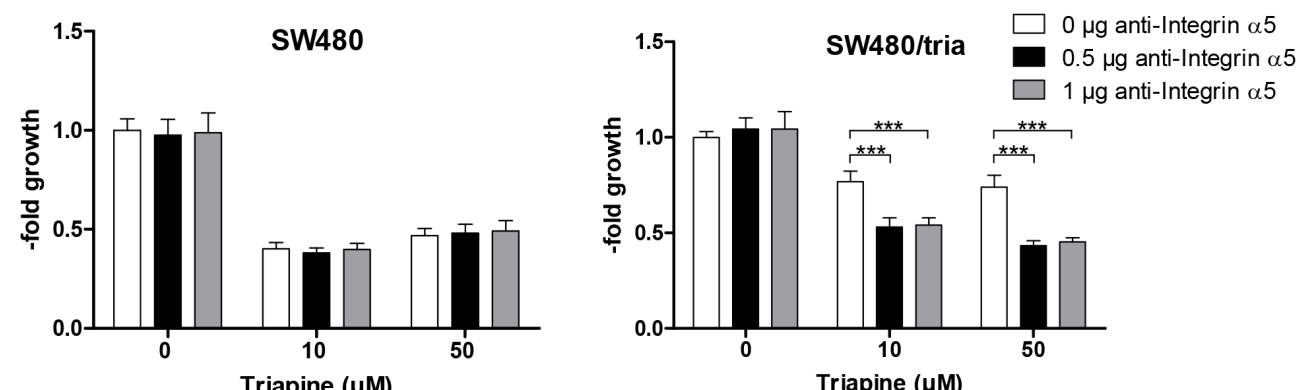

sw480
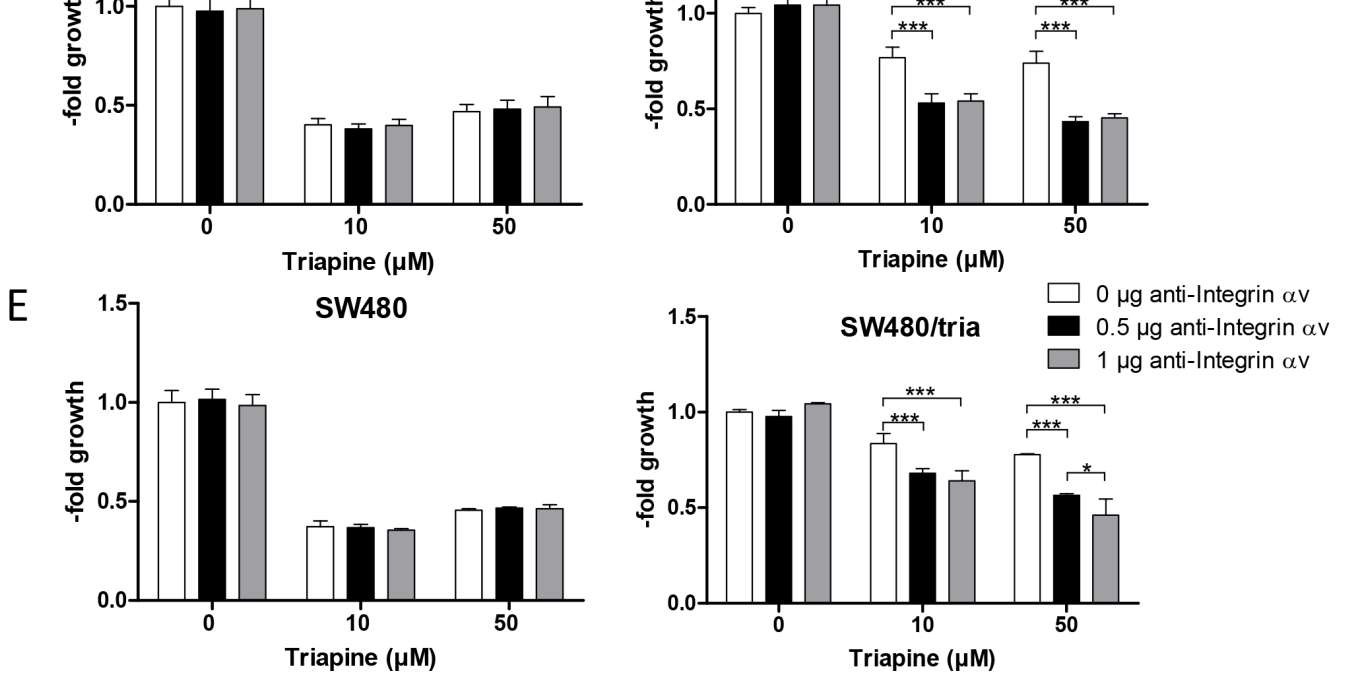

Figure 5: Role of integrins in acquired triapine resistance of $\mathbf{S W 4 8 0 / t r i a ~ c e l l s . ~} \mathbf{A}$. and $\mathbf{B}$. Levels of integrin $\alpha v, \alpha 5, \beta 1$, and $\beta 5$ in plasma membrane-enriched protein fractions (A) and in total protein extracts prepared from SW480 and SW480/tria cells treated as indicated (B) were determined by Western blotting. $\beta$-actin was used as loading control. C. SW480 and SW480/tria cells were treated with the indicated concentrations of triapine alone and in combination with cilengitide. After $72 \mathrm{~h}$ treatment, cell viability was determined by MTT assay. The values given are means and SD of one representative experiment out of three performed in triplicate. Statistical analysis was performed by two-way ANOVA (***P<0.001). D and E. SW480 and SW480/tria cells were treated with the indicated concentrations of triapine alone and in combination with specific inhibitory antibodies for integrin $\alpha 5$ (D) or integrin $\alpha v$ (E). After $72 \mathrm{~h}$ treatment, cell viability was determined by MTT assay. The values given are means and SD of three independent experiments performed in triplicates. Statistical analysis was performed by two-way ANOVA $(* P<0.05, * * * P<0.001)$. 
it had no further stimulatory effects on the expression of integrin $\alpha v$ and the $\beta$-subunits. To investigate the mechanisms underlying massive expression stimulation of integrin $\alpha 5$ in response to triapine, real-time PCR analyses for the respective ITGA5 mRNA were performed (Supplementary Figure S5C). While upregulation of ITGA5 mRNA was only about two-fold in SW480/tria as compared to the parental SW480 cells, short-term triapine exposure induced massive ITGA5 mRNA upregulation in both cell models. This suggests that transcriptional and post-transcriptional mechanisms are involved in the regulation of integrin expression/activity by triapine.

Integrin $\alpha v$ inhibition by cilengitide led to significant triapine re-sensitization of SW480/tria cells, while no synergism was detected in the parental cell line (Figure 5C; Supplementary Figure S5E). Additionally, SW480/ tria cells were per se hypersensitive towards cilengitide when used as single drug (Supplementary Figure S5D). To dissect the role of integrin $\alpha 5$ and $\alpha v$ in acquired triapine resistance, combination experiments of triapine with specific blocking antibodies for these integrin subunits were conducted (Figure 5D and 5E). Interestingly, both antibodies significantly reversed acquired triapine resistance in SW480/tria cells but were widely inactive in the parental cell model. Hence, we conclude that both integrin $\alpha$ subunits play a pivotal role in acquired triapine resistance.

\section{Integrin-mediated cell adhesion is altered by triapine selection}

Integrins are heterodimeric cell surface receptors for ligands in the extracellular matrix leading to activation of intracellular signaling cascades to promote adhesion, migration, proliferation, and survival [34]. To further elucidate altered integrin signaling in triapine resistance, cell adhesion assays with SW480 and SW480/tria cells were performed (Figure 6A). In accordance with the increased expression of several integrin subunits, the triapine-resistant subline was able to adhere moderately but significantly more efficiently to uncoated cell culture plastic as compared to the parental cell line. On surfaces coated with ligands for RGD-binding integrins, namely vitronectin and fibronectin, this difference was distinctly enhanced. In contrast, adhesion to the BSA-coated surface was unaltered in SW480/tria as compared to SW480 cells. Blockade of integrins by cilengitide treatment resulted in reduced cell adhesion efficacy to culture plastic as well as vitronectin and fibronectin, while there was no significant effect in case of BSA. These effects were stronger in the resistant subline in case of the RGD-containing ligands. Furthermore, short-term triapine treatment of both SW480 as well as SW480/tria cells resulted in enhanced adhesion competence to vitronectin but not BSA corresponding to the changes in integrin $\alpha 5$ expression observed in Western blot analyses (Figure 6B; compare Figure 5B). Adherence of both cell models to vitronectin was massively inhibited by Rap1 blockade via zoledronic acid. Presence of triapine abrogated this effect almost completely in the parental but only marginally in the triapine-resistant subline (Figure $6 \mathrm{~B})$. This indicates dominance of the mevalonate pathway/ Rap1 signaling module in triapine-mediated regulation of integrin dynamics in SW480/tria but not SW480 cells.

\section{Possible downstream effectors of Epac-Rap1- integrin-mediated triapine resistance}

Ligand binding by integrin mediates activation of multiple intracellular signaling pathways including MEK/ ERK, PI3K/AKT, and Src, as well as the downstream GTPases RhoA and Rac [34]. To elucidate possible mechanisms underlying Epac/Rapl/integrin-mediated triapine resistance, regulation of these pathways by triapine without and with cilengitide was investigated in SW480 as compared to SW480/tria cells. Phosphorylation of ERK, S6, and Src was used as indicator for activation of the respective pathways (Figure 7A). While both drugs and their combinations had massive impacts on the phosphorylation of ERK, the alterations were widely comparable between SW480 and SW480/tria cells. Phosphorylation of S6 was enhanced in SW480/ tria cells as compared to the parental cell line. Triapine as single agent induced S6 phosphorylation in SW480 but inhibited hyperphosphorylation in SW480/tria cells. In both cell models cilengitide alone massively blocked S6 phosphorylation whereas combination with triapine restored $\mathrm{PI} 3 \mathrm{~K} / \mathrm{AKT}$ pathway activity. The most interesting differences were found in case of Src. Basal phosphorylation was marginally reduced in SW480/ tria, compared to SW480 cells (Figure 7A). Triapine significantly stimulated the level of p-Src in SW480/ tria cells while no effect was seen in the parental cells. Cilengitide as single drug reduced Src phosphorylation in SW480 and SW480/tria cells while combination of both drugs resulted in enhanced Src phosphorylation especially in the resistant subline. Moreover, the triapineresistant subline was moderately but significantly hypersensitive against the Src-inhibitor dasatinib (Figure 7B). Furthermore, Src inhibition led to significant triapine re-sensitization of SW480/tria cells (Figure 7C). The synergistic effect of triapine and dasatinib co-exposure was also confirmed by the respective combination indices (Figure 7D). At low $\mu \mathrm{M}$ triapine concentrations, however, dasatinib also re-sensitized the parental SW480 cells against triapine (Supplementary Figure S6). This indicates that Src phosphorylation is one player underlying acquired as well as intrinsic triapine resistance. Additionally, expression of two additional downstream targets of integrins, namely the GTPases Rac and RhoA, was investigated. Especially basal Rac expression was 
clearly enhanced in triapine-resistant cells compared to the parental cell line. While triapine treatment as single agent reduced Rac and RhoA expression in both cell lines, combination with cilengitide led to enhanced Rac and RhoA levels selectively in SW480/tria cells (Figure 7A). These data suggest cooperation of several integrin-mediated signaling pathways in acquired triapine resistance.

\section{DISCUSSION}

Triapine, the most prominent anticancer thiosemicarbazone, showed promising results in clinical trials against hematological diseases [2, 4] but failed in solid tumors due to unknown reasons so far [5-8]. To investigate in depth the mechanism of acquired triapine resistance, we utilized the human colon carcinoma cell line SW480 and its triapine-resistant subline SW480/ tria [10]. Previously, we have reported on ABCB1 overexpression in this triapine-resistant SW480 subline and the corresponding cross-resistance of SW480/tria cells against several classical chemotherapeutics and substrates of ABCB1-mediated drug efflux. However, inhibition of $A B C B 1$ did not result in significant re-sensitization to triapine suggesting that $\mathrm{ABCB} 1$ overexpression is not the main resistance mechanism in this cell model but rather a general consequence of stress response [10]. Therefore, we aimed to identify additional triapine resistance mechanisms by screening for genome-wide gene dose alterations using aCGH. Interestingly, only minimal additional gene dose changes were caused by long-term triapine selection with the exception of a distinct loss at the chromosomal region

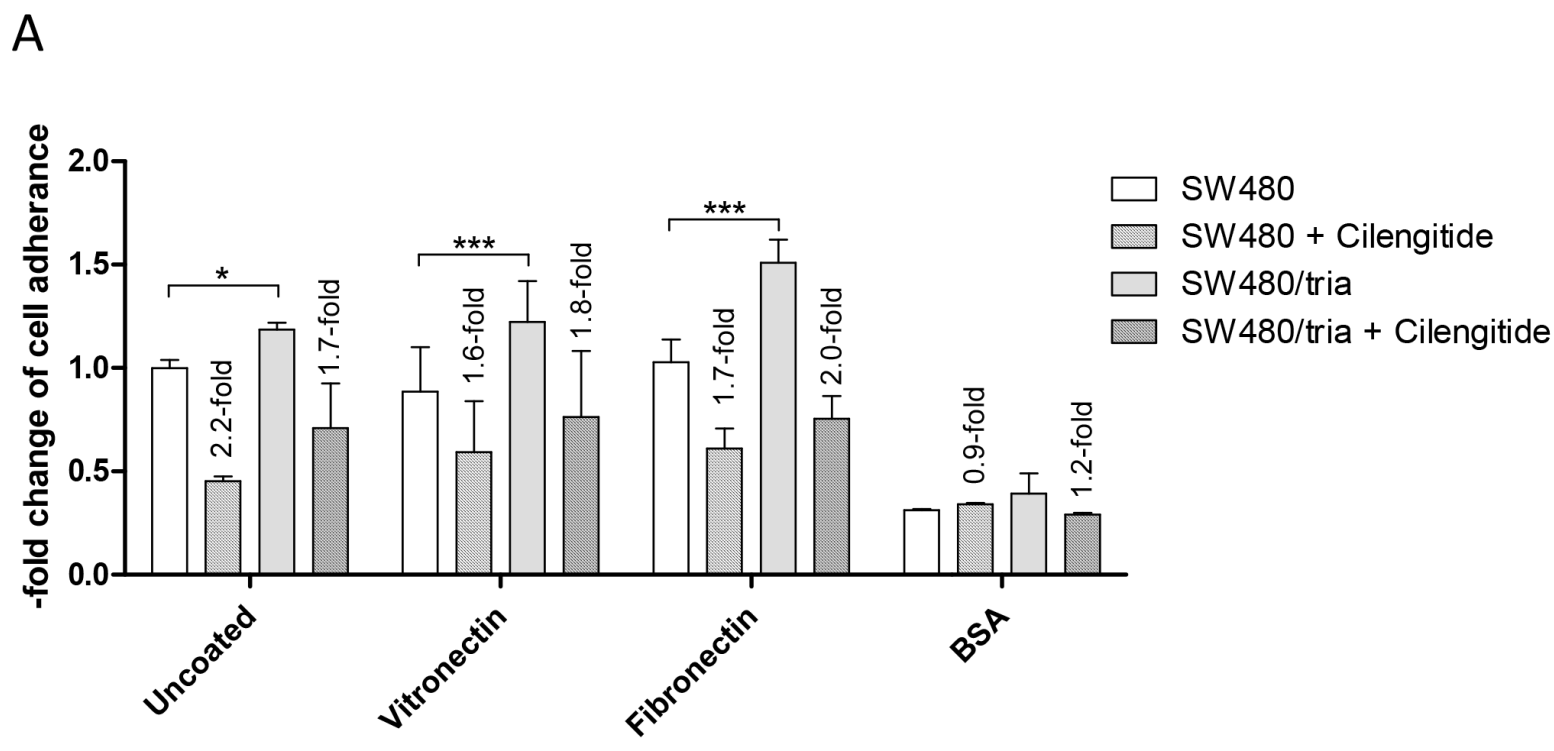

B
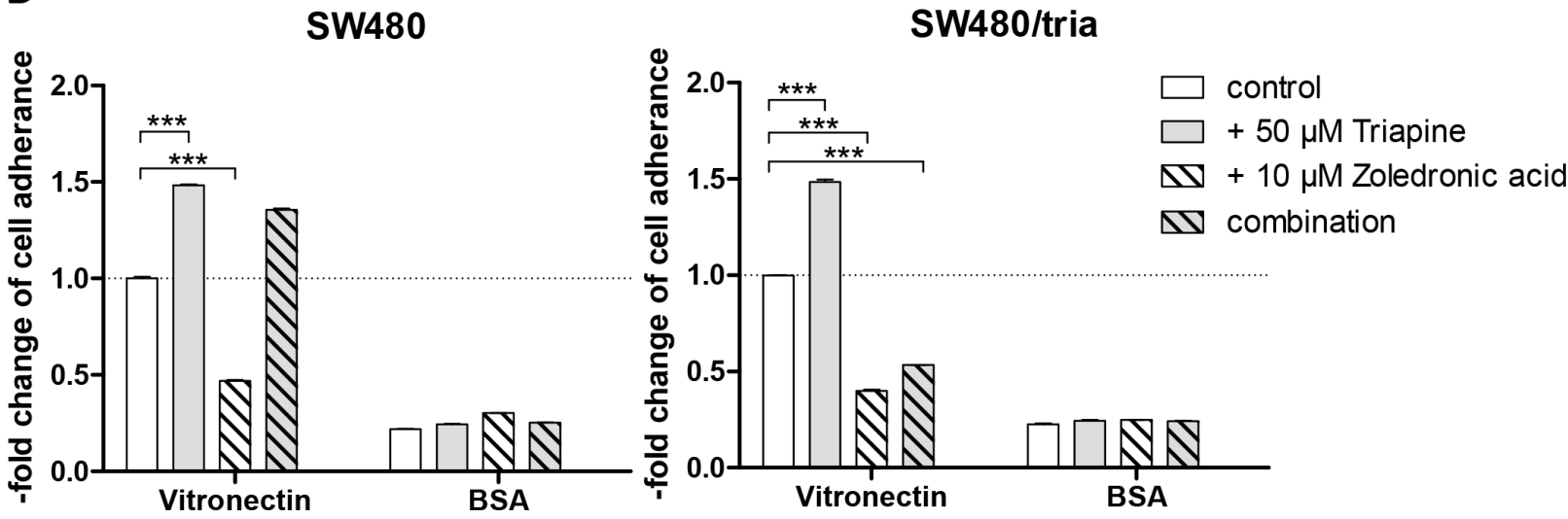

Figure 6: Integrin-mediated cell adhesion in SW480 as compared to $\mathbf{S W 4 8 0 / t r i a}$ cells. A and B. Adhesion of SW480 and SW480/tria cells to the indicated substrates and the impact of $1 \mu \mathrm{M}$ cilengitide (A) and $50 \mu \mathrm{M}$ triapine alone and in combination with $10 \mu \mathrm{M}$ zoledronic acid (B) was analyzed as described in the Material and Methods section. All experiments were repeated three times in duplicates. The means and SD of all three experiments (A) and one representative experiment out of three delivering widely comparable results (B) are shown. Statistical analysis was performed by two-way ANOVA $(* P<0.05, * * * P<0.001)$. 


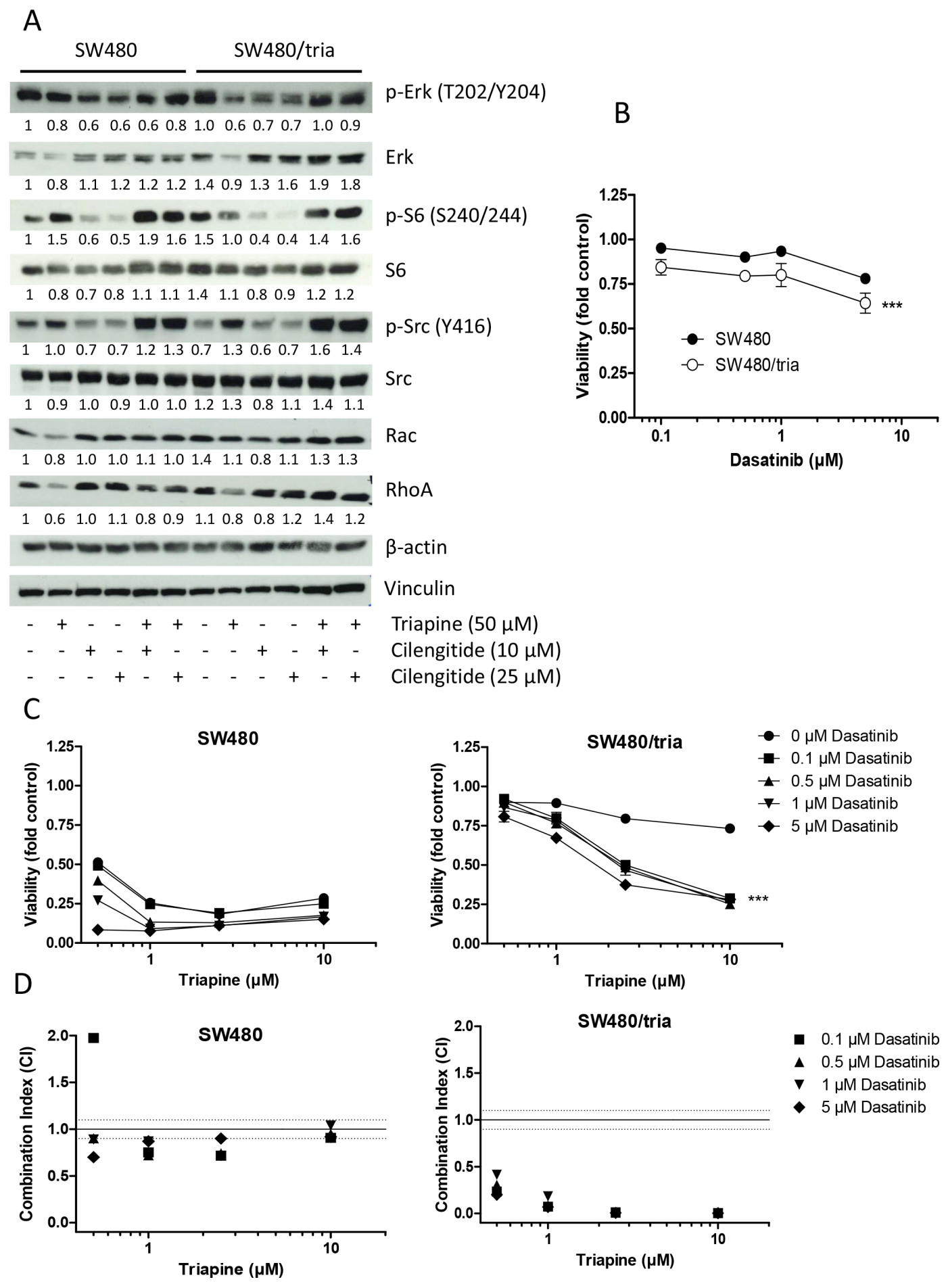

Figure 7: Activation of integrin-mediated downstream signaling pathways in SW480 as compared to SW480/tria cells. A. Activating phosphorylation of Erk (T202/Y204), S6 (S240/244) and Src (Y416) as well as expression of the integrin downstream GTPases Rac and RhoA in SW480 and SW480/tria cells treated with either triapine and cilengitide alone or in combination at the indicated concentrations were determined by Western blot. $\beta$-actin and vinculin were used as loading controls. B and C. SW480 and SW480/tria cells were treated with the indicated concentrations of dasatinib (Src inhibitor) alone (B) and in combination with triapine (C). After $72 \mathrm{~h}$ treatment, cell viability was determined by MTT assay. The values given are means and SD of one representative experiment out of three performed in triplicate. Statistical analysis was performed by two-way ANOVA $(* * * P<0.001)$. D. Combination indices (CI) for the 72 $\mathrm{h}$ analyses shown in $\mathrm{C}$ were calculated using CalcuSyn software. $\mathrm{CI}<0.9, \mathrm{CI}=0.9-1.1$ or $\mathrm{CI}>1.1$ represent synergism, additive effects and antagonism, respectively. 
5 q12 in SW480/tria cells. This homozygous deletion selectively affected the $P D E 4 D$ gene.

In the literature, alterations in phosphodiesterase 4 family members and the resulting changes in cAMP levels were connected with oncogenic but also tumor-suppressive functions. With regard to pro-tumorigenic activities, PDE4 inhibitors were reported to inhibit proliferation, migration, and progression of several solid tumors as well as hematological malignancies probably via cAMP-PKA signaling [35-38]. Accordingly, the cancer-preventive and therapeutic effects of several natural products including curcumin and resveratrol were attributed to PDE4D inhibition $[39,40]$. Furthermore, there is strong evidence for PDE4 to promote angiogenesis via hypoxia-inducible factor in lung cancer [41]. In contrast to these indications of pro-tumorigenic functions, repeatedly homozygous deletions of the PDE4D gene in several malignancies have been reported $[42,43]$. For example, Nancarrow et al. described that homozygous deletion of PDE4D resulted in a tumor suppressor phenotype in esophageal adenocarcinoma [44]. Microdeletions at the PDE4D gene locus in diverse solid tumors resulted in enhanced gene expression and sensitivity towards $P D E 4 D$ knock-down [43]. Moreover, McEwan et al. reported that combination of the PDE4 inhibitor rolipram and low doses of the adenylate cyclase activator forskolin resulted in colon cancer cell growth inhibition implicating that these cells are addicted to maintenance of low cAMP concentrations in a compartment that is regulated by PDE4 [45]. In the present study, deletion of major parts of the $P D E 4 D$-coding region as a consequence of triapine selection resulted in almost complete blockade of gene expression at the mRNA and protein level. Interestingly, this was not accompanied by altered tumorigenicity and growth dynamics as xenograft in SCID mice arguing against a major oncogenic or tumorsuppressive role of PDE4D in the SW480 colon cancer cell model. In contrast, however, we were able to proof an important contribution of PDE4D loss to the triapine resistance phenotype of SW480/tria cells.

PDE4D loss in our resistant cell model resulted in upregulation of cAMP and its major downstream signaling cascade, namely the PKA-Creb axis [16]. Accordingly, PDE4D inhibition in the parental cell line via rolipram and stimulation of cAMP with forskolin resulted in triapine resistance in the parental cell line but did not affect SW480/tria cells. Hence, we hypothesized that this signal module might be the driver for acquired triapine resistance. In line with that, several indications for a role of PKA-Creb activation in oncological therapy failure have been reported. For instance, tamoxifen resistance in hormone receptor-positive and trastuzumab resistance in HER2-positive breast cancer might be mediated via the PKA-Creb axis [46-48]. Moreover, doxorubicin resistance has been associated with hyperactivation of Creb in hepatocellular carcinoma [49] and mesothelioma [50]. In accordance, our triapine-resistant SW480 cells displayed distinct cross-resistance against doxorubicin [10]. However, on the one hand, it has to be kept in mind that SW480/tria cells are overexpressing ABCB1 readily excreting doxorubicin. On the other hand, it is well described that PKA-Creb signaling results in increased $\mathrm{ABCB} 1$ expression and inhibition of this pathway might reverse ABCB1-mediated multi-drug resistance [51, 52]. Furthermore, we have demonstrated previously that the markedly enhanced expression of protein kinase $\mathrm{C}$ (PKC) in SW480/tria cells contributes to ABCB1 overexpression [10]. Interestingly, strong evidence exists for a crosstalk between PKC and PKA-Creb signaling pathways [53] suggesting that PDE4D loss might play a role in ABCB1 overexpression in SW480/tria cells. Surprisingly, however, inhibition of PKA with H-89 did not significantly resensitize SW480/tria cells against triapine. Hence, we had to conclude that the distinctly enhanced PKA-Creb signaling axis in SW480/tria cells is not a major player in acquired triapine resistance.

Due to this fact, we extended our investigation to the more recently discovered second arm of cAMP signaling, namely the Epac-Rap1 axis, which is also hyper-activated in SW480/tria cells. Indeed, Epac activation by 007-AM resulted in triapine resistance of the parental cell line, whereas Epac knock-down and blockade of Rap1 by the prenylation inhibitor zoledronic acid $[54,55]$ re-sensitized SW480/tria against triapine. In contrast to the PKA-Creb axis, the Epac-Rap1 signaling module was unequivocally linked to pro-tumorigenic and resistance-mediating mechanisms. Thus, enhanced Epac expression plays an important role in migration and metastasis in melanoma [56] and pancreatic cancer [29]. Moreover, Onodera et al. described that the Epac-Rap1 signaling pathway regulates glucose uptake and metabolism and therefore promotes oncogenesis [57]. Accordingly, knock-down of RaplA increased sensitivity to taxol in non-small cell lung cancer [58]. It has to be mentioned that Epac represents only one out of several Rap1 GEFs, including for example C3K (Crk SH3-domain-binding guanine nucleotidereleasing factor, also known as RAPGEF1), calcium and diacylglycerol (CalDAG)-GEFs and PDZ-GEF1/2 [59]. Hence, considering the tissue-specific expression of Epac [60], one might hypothesize that also other mechanisms for Rap1 activation in triapine resistance might exist.

Interestingly, the adhesion-mediating but also tumor-promoting functions of cAMP-Rap1 signaling have been repeatedly linked to its impact on integrin expression and activity [61, 62]. Therefore, we decided to investigate whether triapine resistance is based on integrin-mediated survival signaling. Indeed, we observed an increased basal expression of several oncogenic RGD-binding integrin subunits including $\alpha v, \alpha 5, \beta 1$, and $\beta 5$ in the SW480/tria cells especially in plasma membrane-enriched protein fractions. Additionally, we detected a selective stimulation of integrin $\alpha 5$ expression on the mRNA and protein level by short-term triapine treatment. Interestingly, 
the respective $I T G A 5$ mRNA was only about two-fold enhanced in SW480/tria as compared to SW480 cells. However, short-term triapine treatment enhanced ITGA5 mRNA around ten-fold in both cell models while integrin $\alpha v$ was widely unresponsive at mRNA (data not shown) and protein level. This implicates cooperation between broad integrin activation by upstream mechanisms involving Epac-Rap1 signaling in acquired triapine resistance and, additionally, transcriptional upregulation of integrin $\alpha 5$-containing integrin dimers due to an immediate triapine response. The underlying mechanisms are currently dissected in ongoing experiments.

In agreement with enhanced integrin expression, cell adherence of the resistant subline was moderately more efficient to cell culture plastic but distinctly enhanced when using ligands for RGD-binding integrins, namely vitronectin and fibronectin. Furthermore, this adhesion was reduced by the integrin inhibitor cilengitide and the Rap1deprenylating agent zoledronic acid at higher potency in case of the resistant subline. Accordingly, integrin inhibition by cilengitide resulted in re-sensitization of SW480/tria cells to triapine, whereas no effect was observed in the parental cell line. Moreover, combination of both $\alpha 5$ - and $\alpha v$-specific neutralizing antibodies with triapine resulted in significant re-sensitization to triapine in SW480/tria but not the parental SW480 cell model. Together, this strongly suggests that Epac-Rap1-mediated survival signals are mediated by integrin-binding to RGDcontaining ligands resulting in acquired triapine resistance. In line with this observation, several studies reported a role of altered integrin expression and especially subunit $\beta 1$ in resistance against diverse cancer therapeutics in solid tumors [34]. For example, temozolomide resistance in glioblastoma [63] and vemurafenib resistance in melanoma are mediated via $\alpha 5 \beta 1$ integrin-dimer [64], while doxorubicin resistance in leukemia seems to be promoted by $\alpha 2 \beta 1$ [65]. Furthermore, taxol-resistant ovarian carcinoma patients showed a higher expression of integrin $\beta 1$ [66].

When analyzing the most important downstream signaling pathways of integrins, we found a complex impact on both the MAPK and the PI3K/AKT pathways determined by phosphorylation of ERK and S6, respectively. Additionally, interesting differences between SW480 and SW480/tria cells were observed regarding Src phosphorylation. Triapine distinctly upregulated activating Src phosphorylation at Y416 specifically in the resistant subline. While, in accordance with the literature [67], Src phosphorylation was inhibited by cilengitide as single compound, combination with triapine synergistically enhanced this effect especially in SW480/ tria cells to levels far above the control. Interestingly, the triapine-resistant cells exhibited a mild hypersensitivity to the Src inhibitor dasatinib. Combination of triapine with dasatinib markedly restored triapine sensitivity of SW480/tria cells. However, at lower concentrations also in SW480 cells markedly synergistic effects were observed. These data suggest that integrin-mediated Src activation is a player in both intrinsic and acquired triapine resistance. In accordance, multiple studies have suggested an important role of integrin-mediated Src hyperactivation in resistance against antineoplastic drugs but also diverse anticancer kinase inhibitors [68-71]. However, none of these studies reported upstream signaling via the EpacRap1 signal cascade. Additionally to Src, we also found indications that expression of the integrin-downstream GTPases RhoA and Rac might be differently affected by triapine and cilengitide in SW480 and SW480/tria cells. While triapine suppressed expression of these effector molecules, combination with cilengitide led to overexpression especially in the triapine resistant cell model. The hyperactivation of both Src phosphorylation and RhoA GTPase expression, both known to promote drug resistance [68-73], in the synergistic combination between cilengitide and triapine especially in SW480/tria cells is enigmatic. Currently, we follow the hypothesis that these effects are already reflecting escape mechanisms of the cells to survive this effective combination treatment.

Taken together, in the here presented study we established the cAMP-Epac-Rap1-integrin axis as a molecular survival mechanism to protect cancer cells from triapine-mediated cytotoxicity. Whether this mechanism is triapine-specific or might support other multi-drug resistance phenotypes needs to be established. The very broad MDR phenotype of SW480/tria cells not only against ABCB1 substrates [10] but also diverse other cytotoxic and antimetabolic drugs points into that direction. Remarkably enough, also lapatinib-resistant breast cancer as well as erlotinib-resistant non-small cell lung cancer cells harbored increased integrin $\beta 1$ expression and Src phosphorylation levels [68, 69] suggesting also a contribution to tyrosine kinase inhibitor resistance. The druggability of several steps in this resistance signaling axis at the level of cAMP, Rap1, integrin and Src activation implies combination strategies as a suitable approach for overcoming triapine insensitivity of solid tumors in clinical studies.

\section{MATERIALS AND METHODS}

\section{Reagents and cells}

3-Aminopyridine-2-carboxaldehyde thiosemicarbazone (triapine) was synthesized at the Institute of Inorganic Chemistry of the University of Vienna [74]. H-89 dihydrochloride was purchased from Tocris Bioscience (Bristol, UK), 8-(4-Chlorophenylthio)2'-O-methyladenosine-3',5'-cyclic monophosphate, acetoxymethyl ester (007-AM) from BioLog Life Science Institute (Bremen, Germany), cilengitide from Merck KGaA (Darmstadt, Germany) and dasatinib from Selleck Chemicals (TX, USA). Neutralizing anti-integrin $\alpha v$ (272- 
17E6; ab16821) and $\alpha 5$ (P1D6; ab78614) antibodies were purchased from Abcam (Cambridge, UK). Zoledronic acid and all other compounds were supplied by Sigma-Aldrich (MO, USA).

The human colon carcinoma-derived cell lines HCT116 (kindly provided by Dr. Vogelstein, John Hopkins University, Baltimore, MD) and SW480 (ATCC) together with the triapine-resistant subline SW480/tria established by our group [10] were used in this study. HCT-116 was grown in McCoy's and SW480 in minimum essential medium (MEM) supplemented with 10\% FCS.

\section{Cell viability assay}

Cell viability was determined by seeding $2 \mathrm{x}$ $10^{4}$ cells $/ \mathrm{ml}$ on 96 -well plates $(100 \mu \mathrm{l} /$ well). After a recovery period of $24 \mathrm{~h}$, cells were treated with the test drugs for another $72 \mathrm{~h}$. Cell viability was measured by the 3-(4,5-dimethylthiazol-2-yl)-2,5-diphenyltetrazolium bromide (MTT)-based vitality assay (EZ4U; Biomedica, Vienna, Austria) as published [75]. GraphPad Prism software was used to estimate cell viability expressed as $\mathrm{IC}_{50}$ values calculated from full dose-response curves (representing the drug concentrations inducing a 50\% reduction of viable cells in comparison to untreated control cells cultured in parallel).

The presence of synergy was determined using the CalcuSyn software (Biosoft, Ferguson, MO, USA) according to the Chou-Talalay method [76] and expressed by the combination index $(\mathrm{CI})$. CI $<0.9$ represents synergism, $\mathrm{CI}=0.9-1.1$ indicates pure additivity and a $\mathrm{CI}$ $>1.1$ points to antagonism.

\section{Western blot analysis}

Cells were treated for $24 \mathrm{~h}$ at the indicated concentrations with the respective drugs. Total protein lysates were prepared, separated, and transferred onto a polyvinylidene difluoride membrane for Western blotting as described previously [75]. Following antibodies were used: Santa Cruz Biotechnology Inc (CA, USA): PDE4D (\#sc-25100), 1:200; Rap1 (\#sc-65) 1:1000; deprenylated Rap1 (C-17; Rap1A, \#sc-65) 1:1000. Cell signaling Technology (MA, USA): phospho-PKA substrate (\#9624), 1:1000; Creb (\#9104), 1:1000; phospho-Creb (Ser133; \#9198), 1:1000; Epac1 (\#4155), 1:1000; Integrin $\alpha 5$ (\#4705), 1:1000; Integrin $\alpha \nu$ (\#4711), 1:1000; Integrin $\beta 1$ (\#9699), 1:1000; Integrin $\beta 5$ (\#3629), 1:1000; phosphoErk (Thr202/Tyr204; \#9101), 1:1000; Erk (\#9102), 1:1000; phospho-S6 (Ser240/244; \#2215), 1:1000; S6 (\#2317), 1:1000; phospho-Src (Tyr416; \#2101), 1:1000; Src (\#2109), 1:1000; Rac (\#2465), 1:1000; RhoA (67B9; \#2117), 1:1000, and Vinculin (E1E9V, \#13901). SigmaAldrich: $\beta$-actin (AC-15; \#A1978), 1:1000. Secondary, horseradish peroxidase-labeled antibodies from Cell Signaling Technologies were used in working dilutions of $1: 10000$.

\section{Cell cycle analysis}

SW480 and SW480/tria cells $\left(3 \times 10^{5}\right)$ were seeded in 6-well plates and allowed to recover for $24 \mathrm{~h}$. Then, cells were treated with triapine and rolipram at the indicated concentrations for another $24 \mathrm{~h}$ at $37^{\circ} \mathrm{C}$. Cells were trypsinized, treated with RNAse A $(0.2 \mathrm{mg} / \mathrm{ml})$ and stained with propidium iodide $(0.01 \mathrm{mg} / \mathrm{ml})$. Fluorescence of propidium iodide was measured by flow cytometry using FACS Calibur (Becton Dickinson, Palo Alto, CA) as described previously [77]. CellQuest Pro software (Becton Dickinson) was used to analyze the resulting DNA histograms.

\section{Colony formation assay}

Cells were plated at a density of $3.5 \times 10^{3}$ cells/ well in 6-well plates. After $24 \mathrm{~h}$, cells were treated with triapine and rolipram at the indicated concentrations and incubated for 10 days. Afterwards, cells were washed with phosphate-buffered saline (PBS), fixed with methanol for $20 \mathrm{~min}$ on $4^{\circ} \mathrm{C}$, washed again and stained with $0.01 \%$ crystal violet. Colonies were counted and evaluated with ImageJ and GraphPad Prism software, respectively.

\section{Array comparative genomic hybridization (aCGH)}

For aCGH analyses 4x44K oligonucleotide-based microarrays (Agilent) were used. Labeling and hybridization procedures were performed according to protocols provided by Agilent as previously described [78]. Direct aCGH was performed to detect differences between SW480 cells and normal human reference DNA and for comparison of SW480/tria to SW480 cells, indirect aCGH was performed: SW480 (instead of normal human reference DNA) was labeled with Cy3 and SW480/tria cells with Cy5.

\section{Whole genome gene expression analysis}

Gene expression arrays were performed using 4x44K whole genome oligonucleotide-based gene expression arrays from Agilent. Labeling and hybridization procedures were performed according to the instructions provided by Agilent using the Quick Amp Labeling Kit and the Two Color Microarray-Based Gene Expression Analysis Protocol as published [78]. Feature extraction and data analysis were carried out using the Feature Extraction and Gene Spring software, respectively. For analysis in GeneSpring following parameters were used (Guided Workflow): samples were thresholded to 1 , shifted to $75 \%$ percentile, and the baseline was set to median of all samples.

\section{Adhesion assay}

Cells were treated with triapine and zoledronic acid at the indicated concentration $24 \mathrm{~h}$ before the 
adhesion assay was performed. Afterwards cells were trypsinized and washed twice with growth medium. $7.5 \times 10^{4}$ cells/well were allowed to adhere for 1 $\mathrm{h}$ on 24-well plates either uncoated or coated with vitronectin (Sigma; \#SRP3186; $3 \mu \mathrm{g} / \mathrm{cm}^{2}$ ), fibronectin (Millipore; \#US1341576; $3 \mu \mathrm{g} / \mathrm{cm}^{2}$ ) or BSA (RothLactan; \#8076.2; $\left.3 \mu \mathrm{g} / \mathrm{cm}^{2}\right)$ in medium without serum. Cilengitide $(1 \mu \mathrm{M})$ was added during the period of adhesion. Afterwards, cells were washed three-times with $\mathrm{PBS}$, fixed with methanol for $20 \mathrm{~min}$ on $4^{\circ} \mathrm{C}$, washed again and stained with $0.01 \%$ crystal violet. Colonies were counted and evaluated with ImageJ and GraphPad Prism software, respectively.

\section{RNA isolation and real-time PCR}

Total RNA was isolated with Trizol reagent. mRNA was transcribed into cDNA and real-time polymerase chain reaction (PCR) was performed as described [79] using following primers: Integrin $\alpha 5$ (ITGA5) sense: 5'-TGCAGTGTGAGGCTGTGTACA-3' and antisense: 5'-GTGGCCACCTGACGCTCT-3'; Integrin $\alpha v$ (ITGAV) sense: 5'-AATCTTCCAATTGAGGATATCAC-3' and antisense: 5'-AAAACAGCCAGTAGCAACAAT-3'. $\beta$-actin sense: 5'-GGATGCAGAAGGA GATCACTG-3' and antisense: 5'-CGATCCACACGGAGTACTTG-3'. $\beta$-actin served as a housekeeping control.

\section{Rap1 activation assay}

$2 \times 10^{7}$ cells were seeded in $150 \mathrm{~cm}^{2}$ flasks. After 24 $\mathrm{h}$ recovery time, cells were harvested, lysed and treated according to manufacturer's protocol (Cell Signaling Technology; Active Rap1 Detection Kit, \#8818).

\section{Xenograft experiments and immunohistochemistry}

Six to eight week old male CB-17 scid/scid (SCID) mice were purchased from Harlan Laboratories and kept in groups of four per cage in a pathogen-free environment. $1 \times 10^{6} \mathrm{SW} 480$ or SW480/tria cells diluted in serum-free RPMI were injected subcutaneously into the right flank of the animals. Tumor size (caliper measurement) was assessed every second day. Tumor volume was calculated using the formula (length $\mathrm{x}$ width $^{2}$ )/2. All experiments were authorized by the Ethics committee at the Medical University Vienna and carried out according to the Austrian and the Federation of Laboratory Animal Science Associations (FELASA). For histological evaluations, 3 $\mu \mathrm{m}$ formalin-fixed and paraffin-embedded tumor sections were deparaffinised and rehydrated. Sections were stained with hematoxylin and eosin (H\&E), Ki-67 (clone MiB1; DAKO, Glostrup, Denmark) 1:100, and integrin $\beta 1$ (CD29, \#610467; BD Bioscience, NJ, USA) 1:400 as described previously [80].

\section{ACKNOWLEDGMENTS}

We are indebted to Gerhard Zeitler for animal care and Irene Herbacek for fluorescence-activated cell sorting analysis. This work was supported by Austrian Science Fond (FWF) grants L212-B11 (to W. Berger) and P22072-B11 (to W. Berger).

\section{CONFLICTS OF INTEREST}

The authors declare no conflicts of interest.

\section{REFERENCES}

1. Yu Y, Wong J, Lovejoy DB, Kalinowski DS, Richardson DR. Chelators at the cancer coalface: desferrioxamine to Triapine and beyond. Clin Cancer Res. 2006; 12:6876-6883.

2. Karp JE, Giles FJ, Gojo I, Morris L, Greer J, Johnson B, Thein M, Sznol M, Low J. A phase I study of the novel ribonucleotide reductase inhibitor 3-aminopyridine-2carboxaldehyde thiosemicarbazone (3-AP, Triapine) in combination with the nucleoside analog fludarabine for patients with refractory acute leukemias and aggressive myeloproliferative disorders. Leuk Res. 2008; 32:71-77.

3. Kolberg M, Strand KR, Graff P, Andersson KK. Structure, function, and mechanism of ribonucleotide reductases. Biochim Biophys Acta. 2004; 1699:1-34.

4. Giles FJ, Fracasso PM, Kantarjian HM, Cortes JE, Brown RA, Verstovsek S, Alvarado Y, Thomas DA, Faderl S, Garcia-Manero G, Wright LP, Samson T, Cahill A, et al. Phase I and pharmacodynamic study of Triapine, a novel ribonucleotide reductase inhibitor, in patients with advanced leukemia. Leuk Res. 2003; 27:1077-1083.

5. Attia S, Kolesar J, Mahoney MR, Pitot HC, Laheru D, Heun J, Huang W, Eickhoff J, Erlichman C, Holen KD. A phase 2 consortium (P2C) trial of 3-aminopyridine-2carboxaldehyde thiosemicarbazone (3-AP) for advanced adenocarcinoma of the pancreas. Invest New Drugs. 2008; 26:369-379.

6. Knox JJ, Hotte SJ, Kollmannsberger C, Winquist E, Fisher B, Eisenhauer EA. Phase II study of Triapine in patients with metastatic renal cell carcinoma: a trial of the National Cancer Institute of Canada Clinical Trials Group (NCIC IND.161). Invest New Drugs. 2007; 25:471-477.

7. Ocean AJ, Christos P, Sparano JA, Matulich D, Kaubish A, Siegel A, Sung M, Ward MM, Hamel N, EspinozaDelgado I, Yen Y, Lane ME. Phase II trial of the ribonucleotide reductase inhibitor 3-aminopyridine-2carboxaldehydethiosemicarbazone plus gemcitabine in patients with advanced biliary tract cancer. Cancer Chemother Pharmacol. 2011; 68:379-388.

8. Traynor AM, Lee JW, Bayer GK, Tate JM, Thomas SP, Mazurczak M, Graham DL, Kolesar JM, Schiller JH. A phase II trial of triapine (NSC\# 663249) and gemcitabine 
as second line treatment of advanced non-small cell lung cancer: Eastern Cooperative Oncology Group Study 1503. Invest New Drugs. 2010; 28:91-97.

9. Rappa G, Lorico A, Liu MC, Kruh GD, Cory AH, Cory JG, Sartorelli AC. Overexpression of the multidrug resistance genes mdr1, mdr3, and mrp in L1210 leukemia cells resistant to inhibitors of ribonucleotide reductase. Biochem Pharmacol. 1997; 54:649-655.

10. Miklos W, Pelivan K, Kowol CR, Pirker C, DornetshuberFleiss R, Spitzwieser M, Englinger B, van Schoonhoven S, Cichna-Markl M, Koellensperger G, Keppler BK, Berger W, Heffeter P. Triapine-mediated ABCB1 induction via $\mathrm{PKC}$ induces widespread therapy unresponsiveness but is not underlying acquired triapine resistance. Cancer Lett. 2015; 361:112-120.

11. Rodriguez CI, Setaluri V. Cyclic AMP (cAMP) signaling in melanocytes and melanoma. Arch Biochem Biophys. 2014; 563:22-27.

12. Banerjee U, Cheng X. Exchange protein directly activated by cAMP encoded by the mammalian rapgef3 gene: Structure, function and therapeutics. Gene. 2015.

13. Almeida MQ, Stratakis CA. How does cAMP/protein kinase A signaling lead to tumors in the adrenal cortex and other tissues? Mol Cell Endocrinol. 2011; 336:162-168.

14. Conti M, Beavo J. Biochemistry and physiology of cyclic nucleotide phosphodiesterases: essential components in cyclic nucleotide signaling. Annu Rev Biochem. 2007; 76:481-511.

15. Huston E, Houslay TM, Baillie GS, Houslay MD. cAMP phosphodiesterase-4A1 (PDE4A1) has provided the paradigm for the intracellular targeting of phosphodiesterases, a process that underpins compartmentalized cAMP signalling. Biochem Soc Trans. 2006; 34:504-509.

16. Rosenberg D, Groussin L, Jullian E, Perlemoine K, Bertagna $\mathrm{X}$, Bertherat J. Role of the PKA-regulated transcription factor CREB in development and tumorigenesis of endocrine tissues. Ann N Y Acad Sci. 2002; 968:65-74.

17. Cheng X, Ma Y, Moore M, Hemmings BA, Taylor SS. Phosphorylation, activation of cAMP-dependent protein kinase by phosphoinositide-dependent protein kinase. Proc Natl Acad Sci U S A. 1998; 95:9849-9854.

18. Taylor SS, Buechler JA, Yonemoto W. cAMP-dependent protein kinase: framework for a diverse family of regulatory enzymes. Annu Rev Biochem. 1990; 59:971-1005.

19. Benbrook DM, Jones NC. Heterodimer formation between CREB and JUN proteins. Oncogene. 1990; 5:295-302.

20. Levy C, Khaled M, Fisher DE. MITF: master regulator of melanocyte development and melanoma oncogene. Trends Mol Med. 2006; 12:406-414.

21. Freeland K, Boxer LM, Latchman DS. The cyclic AMP response element in the Bcl-2 promoter confers inducibility by hypoxia in neuronal cells. Brain Res Mol Brain Res. 2001; 92:98-106.
22. D'Amico M, Hulit J, Amanatullah DF, Zafonte BT, Albanese C, Bouzahzah B, Fu M, Augenlicht LH, Donehower LA, Takemaru K, Moon RT, Davis R, Lisanti MP, et al. The integrin-linked kinase regulates the cyclin $\mathrm{D} 1$ gene through glycogen synthase kinase 3 beta and cAMP-responsive element-binding protein-dependent pathways. J Biol Chem. 2000; 275:32649-32657.

23. Kawasaki H, Springett GM, Mochizuki N, Toki S, Nakaya M, Matsuda M, Housman DE, Graybiel AM. A family of cAMP-binding proteins that directly activate Rap1. Science. 1998; 282:2275-2279.

24. de Rooij J, Zwartkruis FJ, Verheijen MH, Cool RH, Nijman SM, Wittinghofer A, Bos JL. Epac is a Rap1 guaninenucleotide-exchange factor directly activated by cyclic AMP. Nature. 1998; 396:474-477.

25. Rangarajan S, Enserink JM, Kuiperij HB, de Rooij J, Price LS, Schwede F, Bos JL. Cyclic AMP induces integrinmediated cell adhesion through Epac and Rap1 upon stimulation of the beta 2-adrenergic receptor. J Cell Biol. 2003; 160:487-493.

26. Wang Z, Dillon TJ, Pokala V, Mishra S, Labudda K, Hunter B, Stork PJ. Rap1-mediated activation of extracellular signal-regulated kinases by cyclic AMP is dependent on the mode of Rap1 activation. Mol Cell Biol. 2006; 26:2130-2145.

27. Mukai E, Fujimoto S, Sato H, Oneyama C, Kominato R, Sato Y, Sasaki M, Nishi Y, Okada M, Inagaki N. Exendin-4 suppresses SRC activation and reactive oxygen species production in diabetic Goto-Kakizaki rat islets in an Epacdependent manner. Diabetes. 2011; 60:218-226.

28. Lawson CD, Burridge $\mathrm{K}$. The on-off relationship of Rho and Rac during integrin-mediated adhesion and cell migration. Small GTPases. 2014; 5:e27958.

29. Almahariq M, Tsalkova T, Mei FC, Chen H, Zhou J, Sastry SK, Schwede F, Cheng X. A novel EPAC-specific inhibitor suppresses pancreatic cancer cell migration and invasion. Mol Pharmacol. 2013; 83:122-128.

30. Finch RA, Liu M, Grill SP, Rose WC, Loomis R, Vasquez KM, Cheng Y, Sartorelli AC. Triapine (3-aminopyridine2-carboxaldehyde- thiosemicarbazone): A potent inhibitor of ribonucleotide reductase activity with broad spectrum antitumor activity. Biochem Pharmacol. 2000; 59:983-991.

31. Ntantie E, Gonyo P, Lorimer EL, Hauser AD, Schuld N, McAllister D, Kalyanaraman B, Dwinell MB, Auchampach JA, Williams CL. An adenosine-mediated signaling pathway suppresses prenylation of the GTPase Rap1B and promotes cell scattering. Sci Signal. 2013; 6:ra39.

32. Holz GG, Kang G, Harbeck M, Roe MW, Chepurny OG. Cell physiology of cAMP sensor Epac. J Physiol. 2006; 577:5-15.

33. Scaringi C, Minniti G, Caporello P, Enrici RM. Integrin inhibitor cilengitide for the treatment of glioblastoma: a brief overview of current clinical results. Anticancer Res. 2012; 32:4213-4223. 
34. Blandin AF, Renner G, Lehmann M, Lelong-Rebel I, Martin $\mathrm{S}$, Dontenwill M. beta1 Integrins as Therapeutic Targets to Disrupt Hallmarks of Cancer. Front Pharmacol. 2015; 6:279.

35. Park MH, Lee HS, Lee CS, You ST, Kim DJ, Park BH, Kang MJ, Heo WD, Shin EY, Schwartz MA, Kim EG. p21Activated kinase 4 promotes prostate cancer progression through CREB. Oncogene. 2013; 32:2475-2482.

36. Abramovitch R, Tavor E, Jacob-Hirsch J, Zeira E, Amariglio N, Pappo O, Rechavi G, Galun E, Honigman A. A pivotal role of cyclic AMP-responsive element binding protein in tumor progression. Cancer Res. 2004; 64:1338-1346.

37. Cheng JC, Kinjo K, Judelson DR, Chang J, Wu WS, Schmid I, Shankar DB, Kasahara N, Stripecke R, Bhatia R, Landaw EM, Sakamoto KM. CREB is a critical regulator of normal hematopoiesis and leukemogenesis. Blood. 2008; 111:1182-1192.

38. Simpson BJ, Ramage AD, Hulme MJ, Burns DJ, Katsaros D, Langdon SP, Miller WR. Cyclic adenosine 3',5'-monophosphate-binding proteins in human ovarian cancer: correlations with clinicopathological features. Clin Cancer Res. 1996; 2:201-206.

39. Abusnina A, Keravis T, Zhou Q, Justiniano H, Lobstein A, Lugnier C. Tumour growth inhibition and anti-angiogenic effects using curcumin correspond to combined PDE2 and PDE4 inhibition. Thromb Haemost. 2015; 113:319-328.

40. Tsunoda T, Ishikura S, Doi K, Matsuzaki H, Iwaihara Y, Shirasawa S. Resveratrol induces luminal apoptosis of human colorectal cancer HCT116 cells in three-dimensional culture. Anticancer Res. 2014; 34:4551-4555.

41. Pullamsetti SS, Banat GA, Schmall A, Szibor M, Pomagruk D, Hanze J, Kolosionek E, Wilhelm J, Braun T, Grimminger F, Seeger W, Schermuly RT, Savai R. Phosphodiesterase-4 promotes proliferation and angiogenesis of lung cancer by crosstalk with HIF. Oncogene. 2013; 32:1121-1134.

42. Weir BA, Woo MS, Getz G, Perner S, Ding L, Beroukhim R, Lin WM, Province MA, Kraja A, Johnson LA, Shah K, Sato $\mathrm{M}$, Thomas RK, et al. Characterizing the cancer genome in lung adenocarcinoma. Nature. 2007; 450:893-898.

43. Lin DC, Xu L, Ding LW, Sharma A, Liu LZ, Yang H, Tan P, Vadgama J, Karlan BY, Lester J, Urban N, Schummer M, Doan N, et al. Genomic and functional characterizations of phosphodiesterase subtype 4D in human cancers. Proc Natl Acad Sci U S A. 2013; 110:6109-6114.

44. Nancarrow DJ, Handoko HY, Smithers BM, Gotley DC, Drew PA, Watson DI, Clouston AD, Hayward NK, Whiteman DC. Genome-wide copy number analysis in esophageal adenocarcinoma using high-density singlenucleotide polymorphism arrays. Cancer Res. 2008; 68:4163-4172.

45. McEwan DG, Brunton VG, Baillie GS, Leslie NR, Houslay MD, Frame MC. Chemoresistant KM12C colon cancer cells are addicted to low cyclic AMP levels in a phosphodiesterase 4-regulated compartment via effects on phosphoinositide 3-kinase. Cancer Res. 2007; 67:5248-5257.

46. Bentin Toaldo C, Alexi X, Beelen K, Kok M, Hauptmann M, Jansen M, Berns E, Neefjes J, Linn S, Michalides R, Zwart W. Protein Kinase A-induced tamoxifen resistance is mediated by anchoring protein AKAP13. BMC Cancer. $2015 ; 15: 588$.

47. Phuong NT, Lim SC, Kim YM, Kang KW. Aromatase induction in tamoxifen-resistant breast cancer: Role of phosphoinositide 3-kinase-dependent CREB activation. Cancer Lett. 2014; 351:91-99.

48. Gu L, Lau SK, Loera S, Somlo G, Kane SE. Protein kinase A activation confers resistance to trastuzumab in human breast cancer cell lines. Clin Cancer Res. 2009; 15:7196-7206.

49. Li T, Liu Z, Jiang K, Ruan Q. Angiopoietin2 enhances doxorubin resistance in HepG2 cells by upregulating survivin and Ref-1 via MSK1 activation. Cancer Lett. 2013; 337:276-284.

50. Sayan M, Shukla A, MacPherson MB, Macura SL, Hillegass JM, Perkins TN, Thompson JK, Beuschel SL, Miller JM, Mossman BT. Extracellular signal-regulated kinase 5 and cyclic AMP response element binding protein are novel pathways inhibited by vandetanib (ZD6474) and doxorubicin in mesotheliomas. Am J Respir Cell Mol Biol. 2014; 51:595-603.

51. Scala S, Budillon A, Zhan Z, Cho-Chung YS, Jefferson J, Tsokos M, Bates SE. Downregulation of mdr-1 expression by 8 -Cl-cAMP in multidrug resistant MCF-7 human breast cancer cells. J Clin Invest. 1995; 96:1026-1034.

52. Parissenti AM, Gannon BR, Villeneuve DJ, Kirwanrhude AF, Chadderton A, Gluck S. Lack of modulation of MDR1 gene expression by dominant inhibition of cAMPdependent protein kinase in doxorubicin-resistant MCF-7 breast cancer cells. Int J Cancer. 1999; 82:893-900.

53. Lippo BR, Batista TM, de Rezende LF, Cappelli AP, Camargo RL, Branco RC, Sampaio HC, Protzek AO, Wanderley MI, Arantes VC, Corat MA, Carneiro EM, Udrisar DP, et al. Low-protein diet disrupts the crosstalk between the PKA and PKC signaling pathways in isolated pancreatic islets. J Nutr Biochem. 2015; 26:556-562.

54. Kubista B, Trieb K, Sevelda F, Toma C, Arrich F, Heffeter P, Elbling L, Sutterluty H, Scotlandi K, Kotz R, Micksche M, Berger W. Anticancer effects of zoledronic acid against human osteosarcoma cells. J Orthop Res. 2006; 24:1145-1152.

55. Rogers TL, Wind N, Hughes R, Nutter F, Brown HK, Vasiliadou I, Ottewell PD, Holen I. Macrophages as potential targets for zoledronic acid outside the skeletonevidence from in vitro and in vivo models. Cell Oncol (Dordr). 2013; 36:505-514.

56. Baljinnyam E, Umemura M, Chuang C, De Lorenzo MS, Iwatsubo M, Chen S, Goydos JS, Ishikawa Y, Whitelock JM, Iwatsubo K. Epac1 increases migration of endothelial 
cells and melanoma cells via FGF2-mediated paracrine signaling. Pigment Cell Melanoma Res. 2014; 27:611-620.

57. Onodera Y, Nam JM, Bissell MJ. Increased sugar uptake promotes oncogenesis via EPAC/RAP1 and O-GlcNAc pathways. J Clin Invest. 2014; 124:367-384.

58. Du L, Subauste MC, DeSevo C, Zhao Z, Baker M, Borkowski R, Schageman JJ, Greer R, Yang CR, Suraokar M, Wistuba, II, Gazdar AF, Minna JD, et al. miR-337-3p and its targets STAT3 and RAP1A modulate taxane sensitivity in non-small cell lung cancers. PLoS One. 2012; 7:e39167.

59. Lagarrigue F, Kim C, Ginsberg MH. The Rap1-RIAM-talin axis of integrin activation and blood cell function. Blood. 2016; 128:479-487.

60. Parnell E, Palmer TM, Yarwood SJ. The future of EPACtargeted therapies: agonism versus antagonism. Trends in pharmacological sciences. 2015; 36:203-214.

61. Almahariq M, Chao C, Mei FC, Hellmich MR, Patrikeev I, Motamedi M, Cheng X. Pharmacological inhibition and genetic knockdown of exchange protein directly activated by cAMP 1 reduce pancreatic cancer metastasis in vivo. Mol Pharmacol. 2015; 87:142-149.

62. Lee DH, Lee HR, Shin HK, Park SY, Hong KW, Kim EK, Bae SS, Lee WS, Rhim BY, Kim CD. Cilostazol enhances integrin-dependent homing of progenitor cells by activation of cAMP-dependent protein kinase in synergy with Epac1. J Neurosci Res. 2011; 89:650-660.

63. Janouskova H, Maglott A, Leger DY, Bossert C, Noulet F, Guerin E, Guenot D, Pinel S, Chastagner P, Plenat F, Entz-Werle N, Lehmann-Che J, Godet J, et al. Integrin alpha5beta1 plays a critical role in resistance to temozolomide by interfering with the $\mathrm{p} 53$ pathway in highgrade glioma. Cancer Res. 2012; 72:3463-3470.

64. Fedorenko IV, Abel EV, Koomen JM, Fang B, Wood ER, Chen YA, Fisher KJ, Iyengar S, Dahlman KB, Wargo JA, Flaherty KT, Sosman JA, Sondak VK, et al. Fibronectin induction abrogates the BRAF inhibitor response of BRAF V600E/PTEN-null melanoma cells. Oncogene. 2015.

65. Naci D, El Azreq MA, Chetoui N, Lauden L, Sigaux F, Charron D, Al-Daccak R, Aoudjit F. alpha2beta1 integrin promotes chemoresistance against doxorubicin in cancer cells through extracellular signal-regulated kinase (ERK). J Biol Chem. 2012; 287:17065-17076.

66. McGrail DJ, Khambhati NN, Qi MX, Patel KS, Ravikumar $\mathrm{N}$, Brandenburg CP, Dawson MR. Alterations in ovarian cancer cell adhesion drive taxol resistance by increasing microtubule dynamics in a FAK-dependent manner. Sci Rep. 2015; 5:9529.

67. Chilla A, Bianconi D, Geetha N, Dorda A, Poettler M, Unseld M, Sykoutri D, Redlich K, Zielinski CC, Prager GW. Effects of cilengitide in osteoclast maturation and behavior. Exp Cell Res. 2015; 337:68-75.

68. Huang C, Park CC, Hilsenbeck SG, Ward R, Rimawi MF, Wang YC, Shou J, Bissell MJ, Osborne CK, Schiff R. beta1 integrin mediates an alternative survival pathway in breast cancer cells resistant to lapatinib. Breast Cancer Res. 2011; 13:R84.

69. Kanda R, Kawahara A, Watari K, Murakami Y, Sonoda K, Maeda M, Fujita H, Kage M, Uramoto H, Costa C, Kuwano M, Ono M. Erlotinib resistance in lung cancer cells mediated by integrin beta1/Src/Akt-driven bypass signaling. Cancer Res. 2013; 73:6243-6253.

70. Sansing HA, Sarkeshik A, Yates JR, Patel V, Gutkind JS, Yamada KM, Berrier AL. Integrin alphabeta1, alphavbeta, alpha6beta effectors p130Cas, Src and talin regulate carcinoma invasion and chemoresistance. Biochem Biophys Res Commun. 2011; 406:171-176.

71. Shin DH, Lee HJ, Min HY, Choi SP, Lee MS, Lee JW, Johnson FM, Mehta K, Lippman SM, Glisson BS, Lee HY. Combating resistance to anti-IGFR antibody by targeting the integrin beta3-Src pathway. J Natl Cancer Inst. 2013; 105:1558-1570.

72. Doublier S, Riganti C, Voena C, Costamagna C, Aldieri E, Pescarmona G, Ghigo D, Bosia A. RhoA silencing reverts the resistance to doxorubicin in human colon cancer cells. Mol Cancer Res. 2008; 6:1607-1620.

73. Mokady D, Meiri D. RhoGTPases - A novel link between cytoskeleton organization and cisplatin resistance. Drug Resist Updat. 2015; 19:22-32.

74. Kowol CR, Trondl R, Heffeter P, Arion VB, Jakupec MA, Roller A, Galanski M, Berger W, Keppler BK. Impact of metal coordination on cytotoxicity of 3-aminopyridine-2carboxaldehyde thiosemicarbazone (triapine) and novel insights into terminal dimethylation. J Med Chem. 2009; 52:5032-5043.

75. Heffeter P, Jakupec MA, Korner W, Chiba P, Pirker C, Dornetshuber R, Elbling L, Sutterluty H, Micksche M, Keppler BK, Berger W. Multidrug-resistant cancer cells are preferential targets of the new antineoplastic lanthanum compound KP772 (FFC24). Biochem Pharmacol. 2007; 73:1873-1886.

76. Chou TC. Theoretical basis, experimental design, and computerized simulation of synergism and antagonism in drug combination studies. Pharmacol Rev. 2006; 58:621-681.

77. Dornetshuber-Fleiss R, Heffeter P, Mohr T, Hazemi P, Kryeziu K, Seger C, Berger W, Lemmens-Gruber R. Destruxins: fungal-derived cyclohexadepsipeptides with multifaceted anticancer and antiangiogenic activities. Biochem Pharmacol. 2013; 86:361-377.

78. Mathieu V, Pirker C, Schmidt WM, Spiegl-Kreinecker S, Lotsch D, Heffeter P, Hegedus B, Grusch M, Kiss R, Berger W. Aggressiveness of human melanoma xenograft models is promoted by aneuploidy-driven gene expression deregulation. Oncotarget. 2012; 3:399-413. doi: 10.18632/ oncotarget.473.

79. Fischer H, Taylor N, Allerstorfer S, Grusch M, Sonvilla G, Holzmann K, Setinek U, Elbling L, Cantonati H, 
Grasl-Kraupp B, Gauglhofer C, Marian B, Micksche M, et al. Fibroblast growth factor receptor-mediated signals contribute to the malignant phenotype of non-small cell lung cancer cells: therapeutic implications and synergism with epidermal growth factor receptor inhibition. Mol Cancer Ther. 2008; 7:3408-3419.
80. Jungwirth U, Gojo J, Tuder T, Walko G, Holcmann M, Schofl T, Nowikovsky K, Wilfinger N, Schoonhoven S, Kowol CR, Lemmens-Gruber R, Heffeter P, Keppler BK, et al. Calpain-mediated integrin deregulation as a novel mode of action for the anticancer gallium compound KP46. Mol Cancer Ther. 2014; 13:2436-2449. 